INTERNATIONAL MONETARY FUND

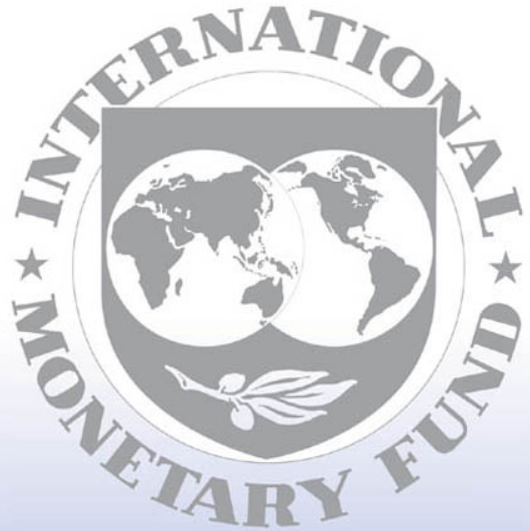

Staff

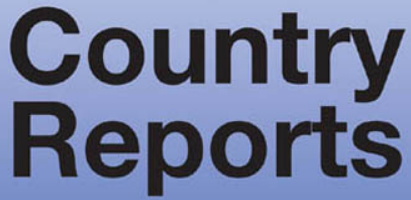




\section{Kuwait: 2008 Article IV Consultation-Staff Report; Staff Statement; Public Information Notice on the Executive Board Discussion; and Statement by the Executive Director for Kuwait}

Under Article IV of the IMF's Articles of Agreement, the IMF holds bilateral discussions with members, usually every year. In the context of the 2008 Article IV consultation with Kuwait, the following documents have been released and are included in this package:

- $\quad$ The staff report for the 2008 Article IV consultation, prepared by a staff team of the IMF, following discussions that ended on January 28, 2008, with the officials of Kuwait on economic developments and policies. Based on information available at the time of these discussions, the staff report was completed on April 2, 2008. The views expressed in the staff report are those of the staff team and do not necessarily reflect the views of the Executive Board of the IMF.

- $\quad$ A staff statement of April 18, 2008, updating information on recent developments.

- $\quad$ A Public Information Notice (PIN) summarizing the views of the Executive Board as expressed during its April 18, 2008 discussion of the staff report that concluded the Article IV consultation.

- $\quad$ A statement by the Executive Director for Kuwait.

The document listed below has been or will be separately released.

Statistical Appendix

The policy of publication of staff reports and other documents allows for the deletion of market-sensitive information.

Copies of this report are available to the public from

International Monetary Fund • Publication Services

$70019^{\text {th }}$ Street, N.W. • Washington, D.C. 20431

Telephone: (202) 623-7430 • Telefax: (202) 623-7201

E-mail: publications@imf.org • Internet: http://www.imf.org

Price: $\$ 18.00$ a copy

\section{International Monetary Fund \\ Washington, D.C.}


This page intentionally left blank

(CInternational Monetary Fund. Not for Redistribution 


\section{INTERNATIONAL MONETARY FUND}

\section{KUWAIT \\ Staff Report for the 2008 Article IV Consultation}

Prepared by Staff Representatives for the 2008 Consultation with Kuwait

Approved by Lorenzo L. Pérez and Scott Brown

April 2, 2008

- The 2008 Article IV consultation discussions were held in Kuwait during January 14-28, 2008.

- $\quad$ The team comprised Messrs. Enders (head), Erbas, Hasan, Prasad, and Williams (all MCD). Mr. Shaalan, Executive Director for Kuwait, and Mr. Khan (MCD) participated in the policy discussions.

- The mission met with Mr. Al-Shamali, Minister of Finance; Sheikh Salem Al-Sabah, Governor, Central Bank of Kuwait (CBK); Dr. Al-Mannae, Deputy Governor, CBK; and other representatives from the government, parliament, academia, and the private sector.

- The previous consultation was concluded on April 6, 2007. The Public Information Notice of the Executive Board's discussion is available at http://www.imf.org/external/np/sec/pr/2007/pr07109.htm

- Kuwait has accepted the obligations of Article VIII, Sections 2, 3, and 4, and maintains an exchange system free of restrictions on the making of payments and transfers for current international transactions, other than certain security-related restrictions notified to the Fund pursuant to Decision 144-(52/51).

- In May 2007, Kuwait abandoned the peg to the U.S. dollar in favor of a peg to an undisclosed currency basket.

- The authorities will consider publishing the staff report following its discussion by the Executive Board. 


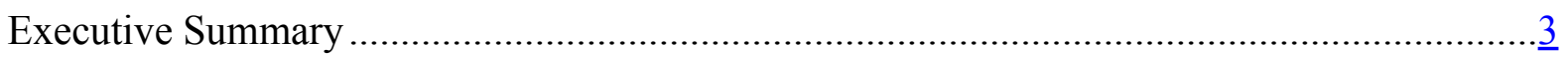

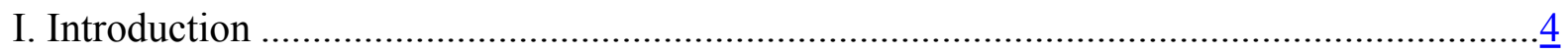

II. Background and Recent Developments ....................................................................

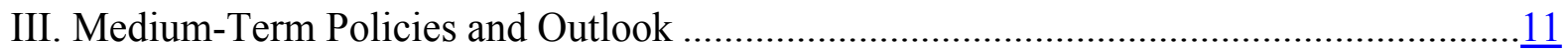

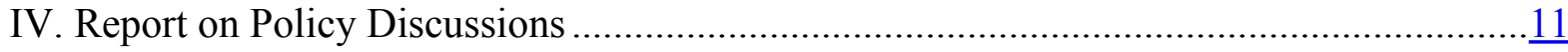

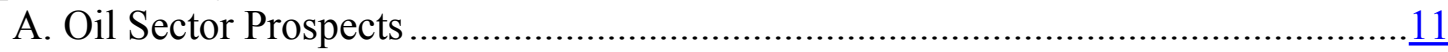

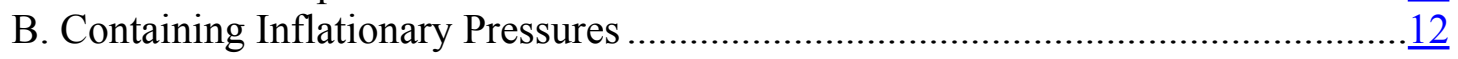

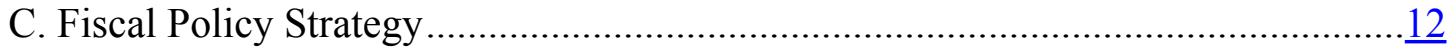

D. Monetary and Exchange Rate Policy and Financial Sector Developments .............13

E. Domestic and External Stability .........................................................................

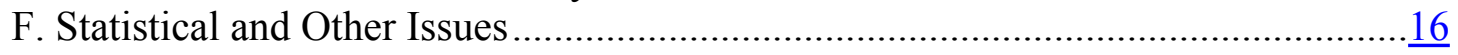

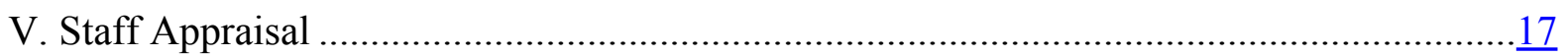

Boxes

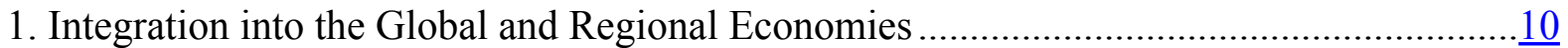

2. Investment Companies - Growing by Leaps and Bounds ..............................................

3. Exchange Rate Assessment for Kuwait .......................................................................

Figures

1. Real GDP, Inflation, Fiscal and Current Account Surpluses..........................................11

2. Distribution of the Investment Plan in the Oil and Gas Sector..........................................

Tables

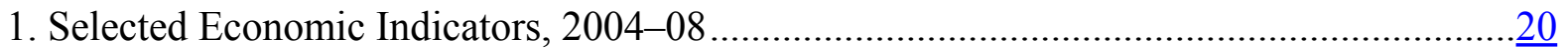

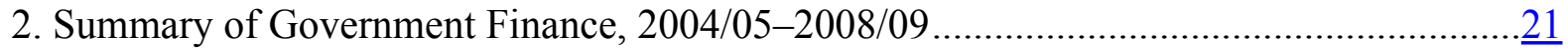

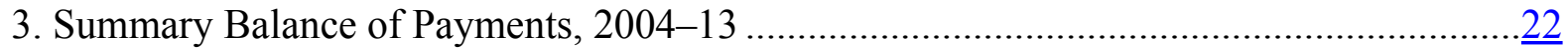

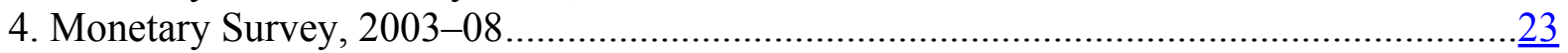

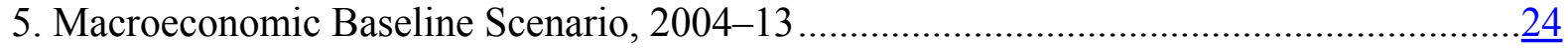

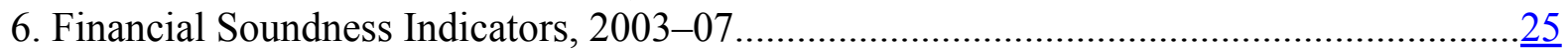

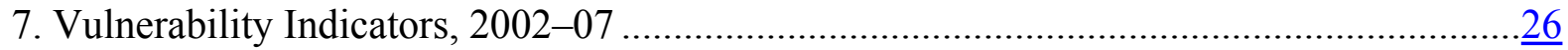




\section{EXECUTIVE SUMMARY}

The 2008 Article IV consultation discussions with Kuwait focused on oil sector prospects, policies to contain inflationary pressures, the fiscal strategy to utilize rising oil wealth, the financial sector, and domestic and external stability in the context of the pegged exchange rate regime.

\section{Economic developments and outlook}

Kuwait's macroeconomic performance has been strong and the outlook remains very favorable. Non-oil GDP continues to expand rapidly and both the fiscal and external current account remain in large surplus. Although oil sector growth is projected to moderate over the medium term, non-oil activities are expected to remain buoyant spurred by rising wealth and confidence, public investment, and structural reforms to support private sector investment growth.

\section{The authorities' views and plans}

- Undertake large-scale investments to expand oil production and refining capacity.

- A fiscal strategy involving higher capital spending, limiting expanding current expenditure, and saving part of the oil wealth to reduce dependency on oil income for funding the budget.

- $\quad$ Continue a basket peg regime that has kept the Kuwaiti dinar (KD) broadly in line with fundamentals, although it constrains the ability to contain credit expansion and speculative capital movements.

\section{Staff recommendations}

- Contain inflationary pressures by enhancing the supply response in the nontradables sector, limiting government current spending to keep the economy from overheating, and slowing credit growth.

- $\quad$ Strengthen further the fiscal framework to balance the objectives of ensuring intergenerational equity, containing inflation, and meeting infrastructural needs of the oil and non-oil sectors.

- In the context of the pegged exchange regime and the easing monetary stance in the U.S., use available tools to restrain credit growth and deter speculative capital flows, and remain vigilant towards possible financial system vulnerabilities.

- $\quad$ Support private sector-led investment and growth by bringing capital market, companies, competition, public-private partnerships and privatization laws in line with best international practice.

- Enhance scope for involving foreign technical know-how in the development of Kuwait's northern oil fields.

- $\quad$ This policy mix should contribute to domestic and external stability, and help address the current moderate undervaluation of the KD. 


\section{INTRODUCTION}

\section{Since last year's Article IV consultation, Kuwait's strong economic and financial} position has improved further, but inflation has risen. Growth in the non-oil economy has been over 9 percent, and the large increase in oil revenue generated substantial fiscal and external current account surpluses, enabling the country to build up the stock of foreign assets. ${ }^{1}$ Structural reforms continued, aimed at promoting a dynamic private sector driven economy and enhancing incentives for bringing in foreign technical know-how.

\section{Kuwait made important progress on the issues raised in the 2007 consultation.}

The authorities announced a schedule to close the actuarial deficit of Kuwait Public Institute for Social Security (KPISS) by 2009, strengthened further the fiscal framework, expanded the privatization program, reduced taxes on foreign investors, worked with parliament to give priority to the capital market law and other draft laws that would facilitate broadening the role of private sector, continued to refine their periodic stress-testing of banks, reaffirmed their commitment to join the GCC monetary union, and continued to apply the Kuwaitization policy flexibly.

3. The discussions focused on oil sector prospects, policies to contain inflationary pressures, the fiscal strategy to utilize rising oil wealth and advancing fiscal reforms, monetary policy and financial sector developments, structural reforms to support private sector-led investment and employment generation, and domestic and external stability.

\footnotetext{
${ }^{1}$ Kuwait has two saving funds managed by the Kuwait Investment Authority (KIA): the Reserve Fund for Future Generations (RFFG) and the General Reserve Fund (GRF), which is primarily a stabilization fund. Ten percent of total government revenue is transferred to RFFG, which also retains its investment income; any budget surplus is transferred to the GRF.
} 


\section{BACKGROUND AND RECENT DEVELOPMENTS ${ }^{2}$}

High non-oil growth ...

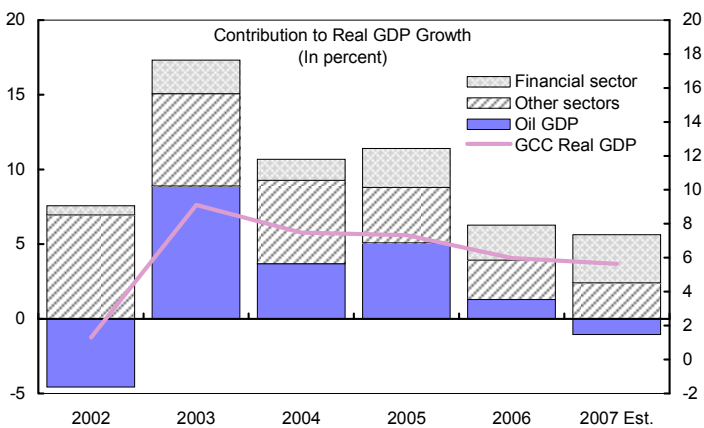

...has created jobs for Kuwaitis and expatriates in the private sector.

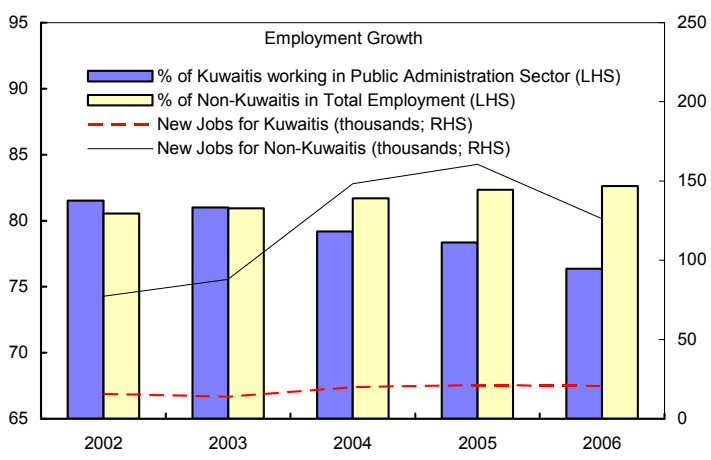

... from external factors (mainly food imports)...

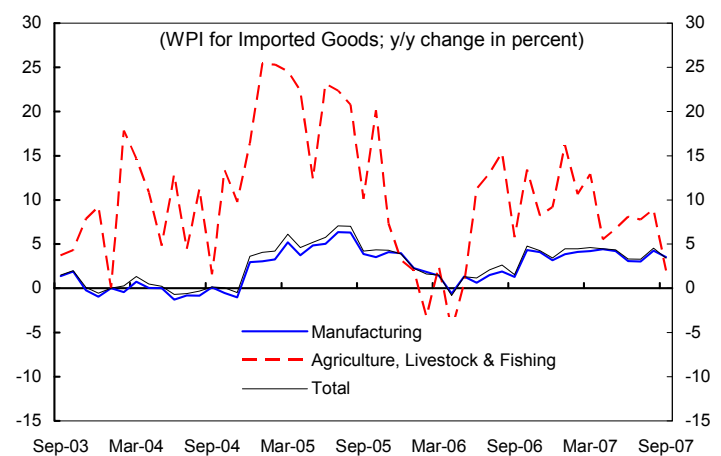

... supported by a pick-up in investment spending...

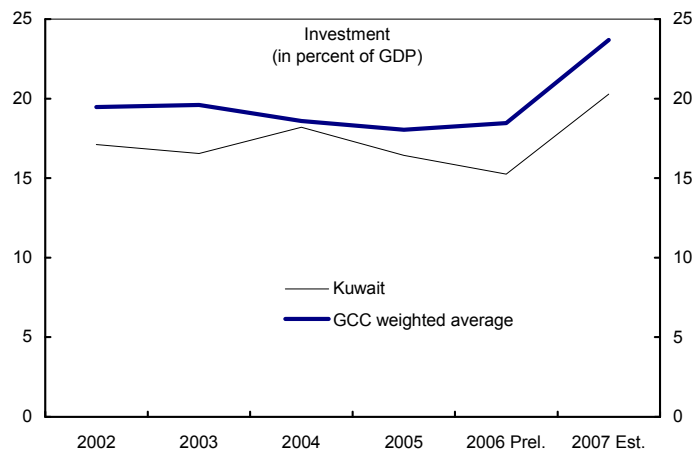

However, inflationary pressures emerged...

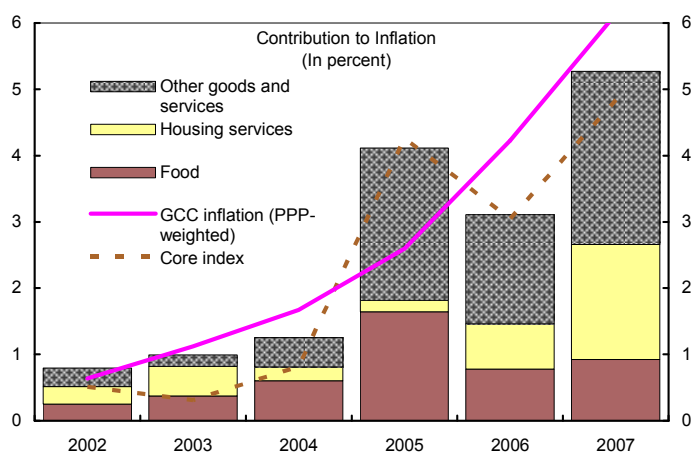

....and domestic factors (especially rents).

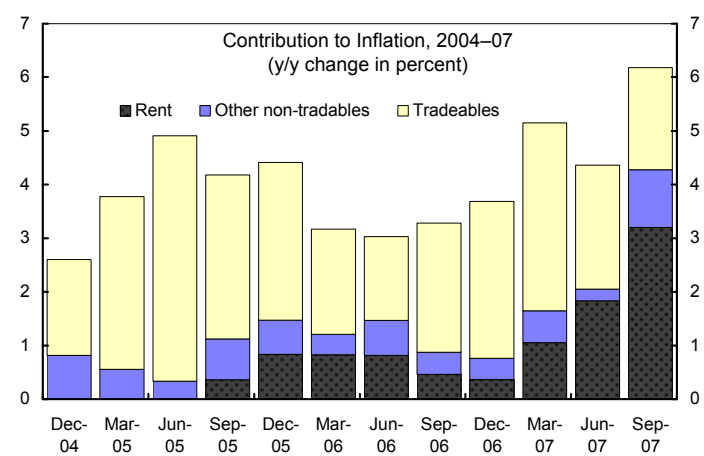

${ }^{2}$ Based on data from Kuwait authorities; Kipco Assets Management Company (KAMCO); National Bank of Kuwait; Data Stream; and Fund staff estimates. 
Real estate prices have increased significantly.

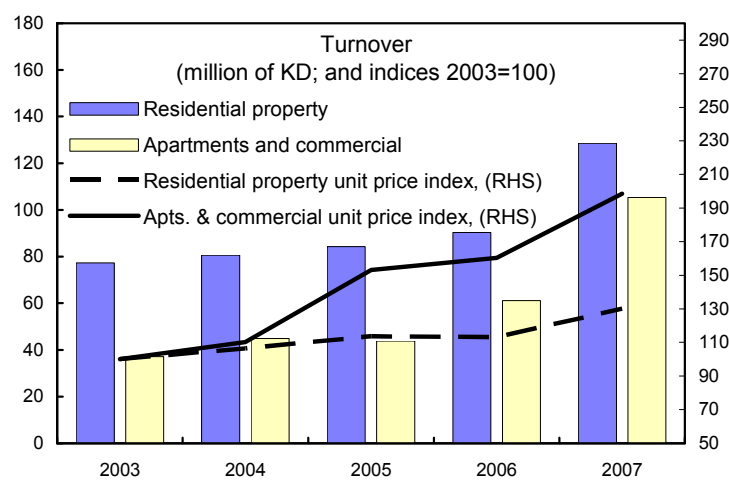

....with relatively modest $P / E$ ratios and dividend yield.

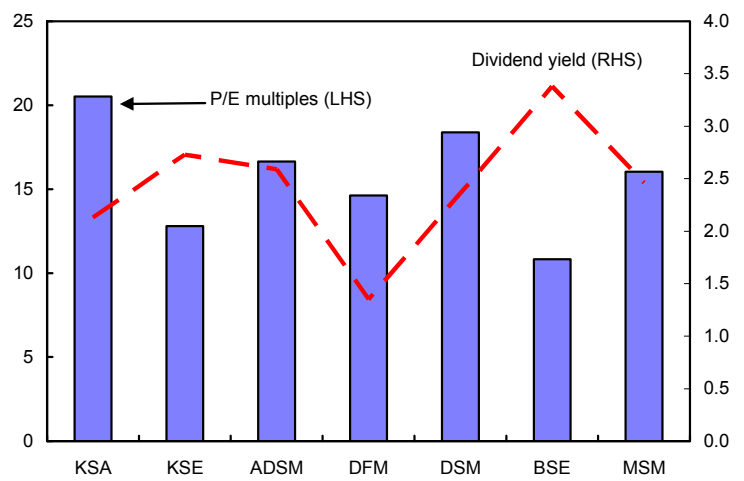

The move coincided with increasing speculation...

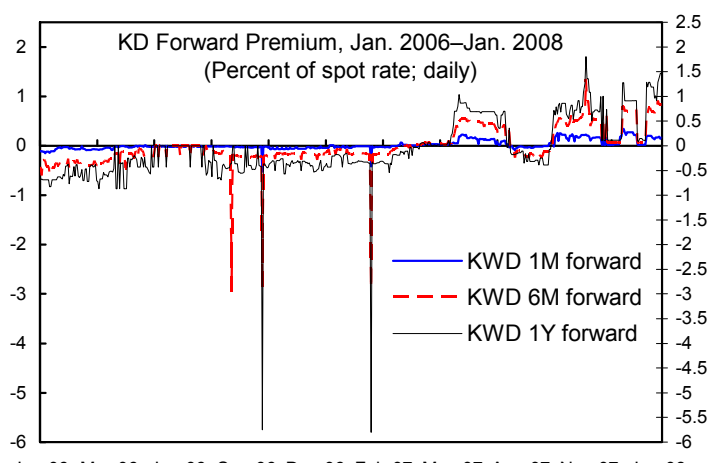

Jan-06 Mar-06 Jun-06 Sep-06 Dec-06 Feb-07 May-07 Aug-07 Nov-07 Jan-08
The Kuwaiti stock market has been one of the best performers in the region...

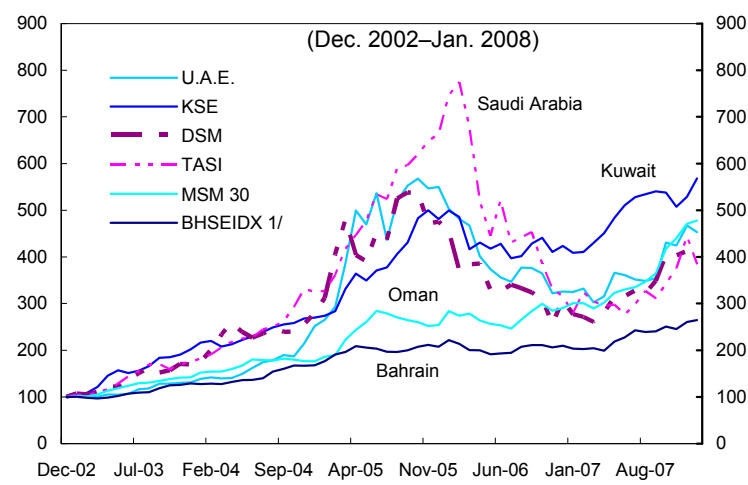

After moving to a basket peg in mid 2007 the KD appreciated by 6 percent against the U.S. dollar.

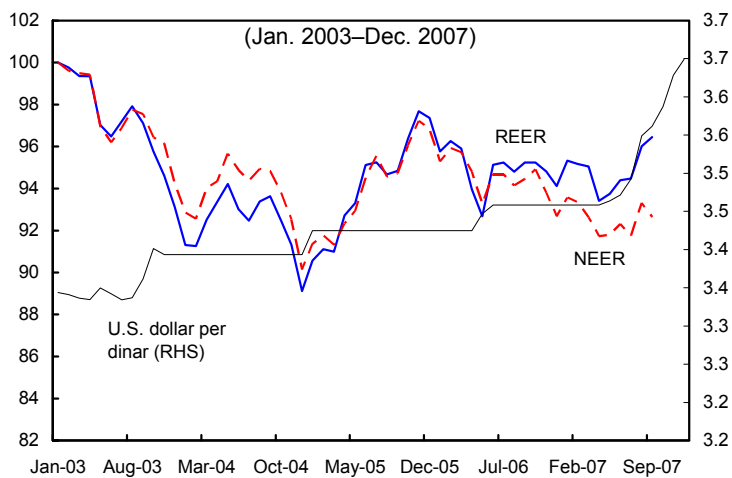

...and large capital inflows.

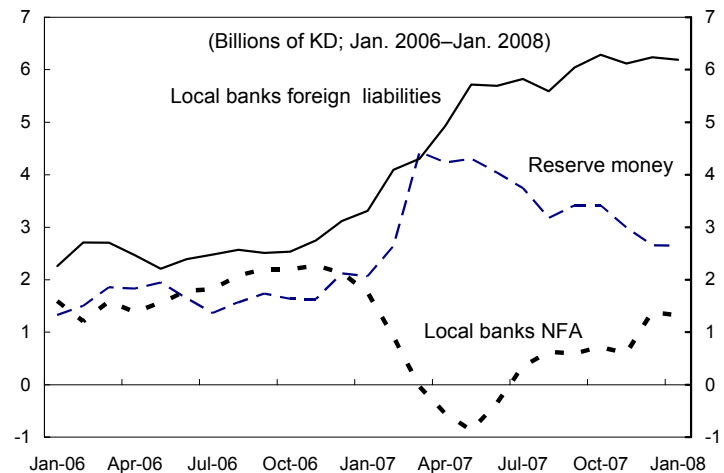


The authorities cut interest rates to discourage speculation...

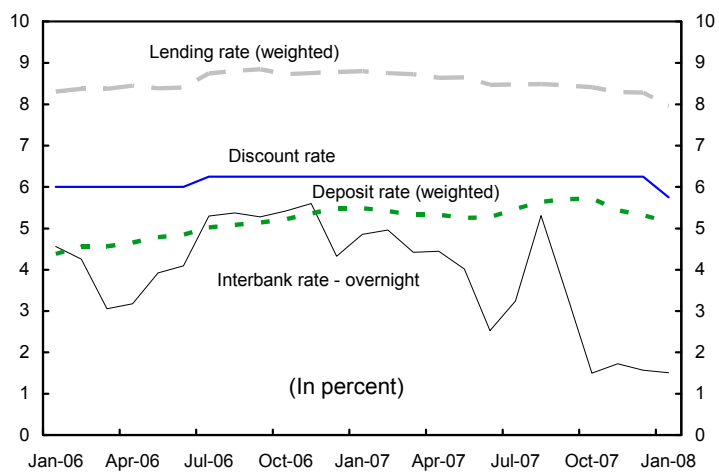

Monetary aggregates continued to expand with strong credit growth...

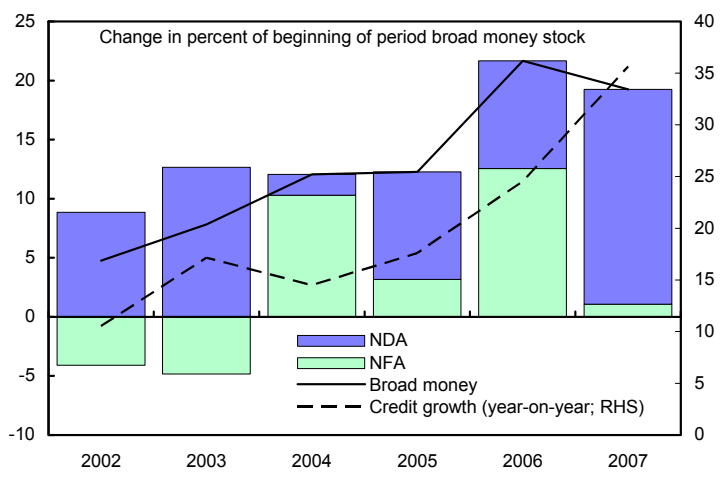

With higher oil revenues, public current and capital expenditures have increased...

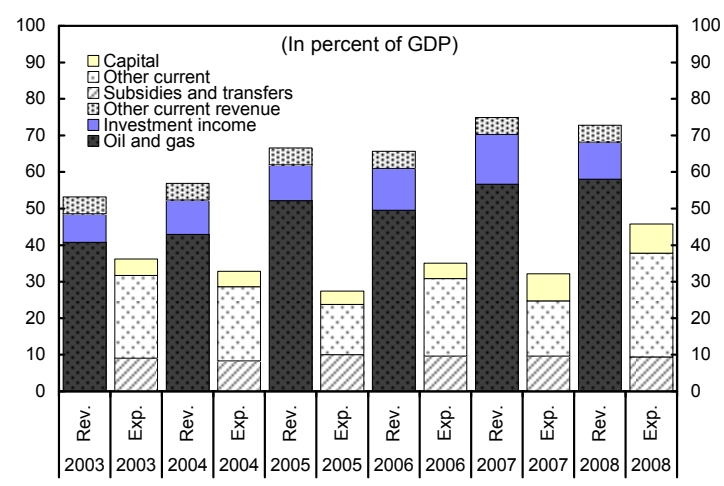

... with the KD interbank rate kept well below LIBOR.

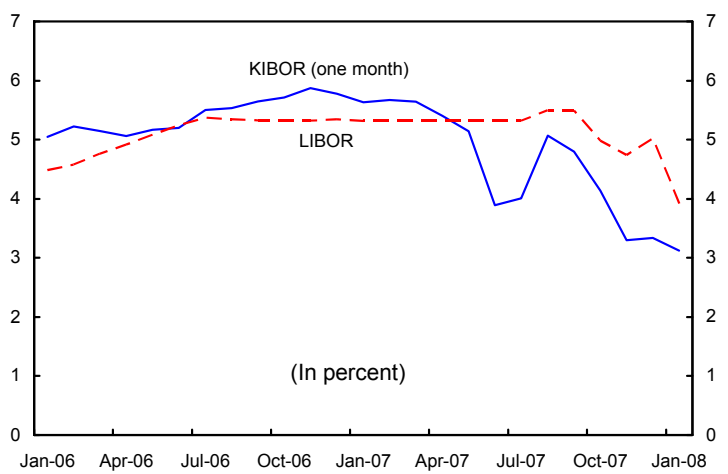

... especially to the real estate sector and personal facilities (mainly consumer loans).

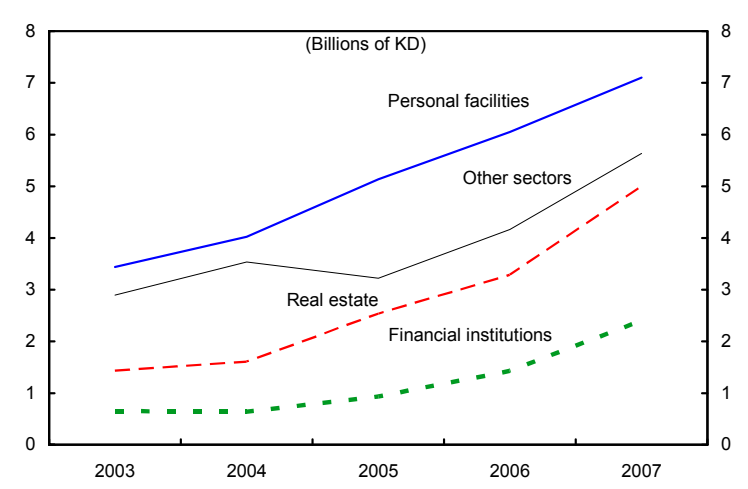

... the overall fiscal balance remained in large surplus but the non-oil deficit (excluding oil and investment income) widened.

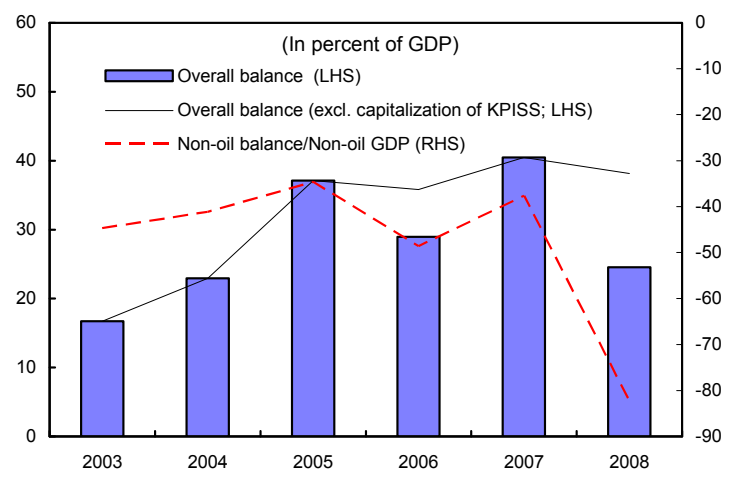


High oil prices have contributed to large current acount surpluses... ...and the rapid accumulation of assets.

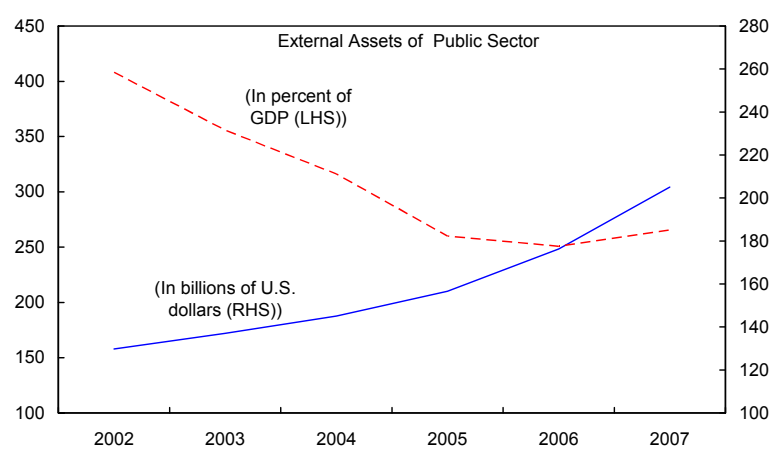

- Growth: Kuwait's oil production declined by 2.6 percent in 2007 in line with decisions by the Organization of Petroleum Exporting Countries (OPEC) (Table 1). Non-oil activity - particularly in financial, transportation, and communication services - grew almost 9 percent, adding jobs in the private sector for both Kuwaitis and non-Kuwaitis, and boosting workers' remittances to poorer countries in Asia and the Middle East.

- Inflation has been gradually picking up, reaching 7 percent y/y in October 2007, driven both by domestic demand pressures (especially rents) and higher import prices (mostly food). Asset prices surged, with a 25 percent increase of the Kuwait Stock Exchange (KSE) index during 2007 and even higher increases in real estate prices.

- Exchange rate: The authorities abandoned the peg to the U.S. dollar in May 2007, and pegged the KD to an undisclosed basket of currencies in an attempt to dampen imported inflation related to rising world food prices and the depreciation of the U.S. dollar. The move coincided with speculative inflows as some market participants expected a large revaluation (similar speculation occurred later in other GCC countries). In the event, the KD appreciated by 5.9 percent against the U.S. dollar during 2007 . The real effective exchange rate (REER) of the KD has been trending upwards since 2005.

- Monetary policy: Within the constraints of the peg, the CBK sought to dampen capital inflows by driving down the KD interbank rate (KIBOR) below LIBOR, and to contain the expansion of monetary aggregates by tightening the 80 percent loan-to-deposit ceiling in place since July 2004, requiring the ratio to be met on average during the month rather than only at the end of the month. Even so, broad money grew by 19 percent and credit to the economy by 36 percent during 2007 (Table 4).

- Fiscal policy continued to be expansionary in 2007 . Overall spending rose by 21 percent in 2006/07 fiscal year, with large spending increases across all categories (Table 2). In addition, the budget made a large one-time payment (KD 2 billions) to the public pension system (KPISS) to reduce its actuarial deficit. The non-oil deficit (excluding income from 
oil and investments and recapitalization transfers to KPISS) rose to 50 percent of non-oil GDP in 2006/07. It is projected to reach 58 percent in 2007/08, driven by continued growth in wages and capital outlays, most recently an increase in cost of living allowances for civil servants ( $1 / 2$ percent of GDP on an annual basis). Even so, the surge in oil revenue during 2007 and early 2008 is expected to result in an increase of the overall budget surplus to 39 percent of GDP for 2007/08.

4. Structural reforms to promote a dynamic open economy driven by the private sector gained some momentum.

The National Assembly approved three economic laws that had been stalled for years:

\begin{abstract}
Reducing the profit tax on foreign investors from 55 percent to 15 percent and exempting capital gains from stock investment from tax. The new legislation removes an important obstacle for the flow of foreign investment into the country.
\end{abstract}

- Sale of state properties law. The law sets guidelines for the government to provide state land to local or foreign investors. It also provides a legal basis for projects involving public-private partnerships (PPPs).

- A bill authorizing the privatization of Kuwait Airways. This would be the first major privatization in Kuwait.

The government granted licenses to three private airlines and four new private universities, and privatized a number of gas stations.

For the first time, budget preparation (including the wage bill and the capital budget) has been consolidated in the ministry of finance, thereby strengthening further the fiscal framework.

$>$ The GCC common market agreement went into effect as of the beginning of 2008. This along with other steps is likely to strengthen further Kuwait's integration in the world economy (see Box 1).

$>$ Progress is being made in implementing the 2003 FSAP mission recommendations; all those pertaining to the central bank have been implemented, except for the removal of the ceiling on lending rates which would require parliamentary approval.

\begin{tabular}{|c|c|c|c|}
\hline \multicolumn{4}{|c|}{ Summary of Status of Implementation of FSAP Key Recommendations } \\
\hline Key Recommendation & $\begin{array}{c}\text { Fully } \\
\text { Implemented }\end{array}$ & $\begin{array}{l}\text { Progress } \\
\text { Made }\end{array}$ & $\begin{array}{c}\text { No } \\
\text { Progress }\end{array}$ \\
\hline Eliminate the blanket deposit guarantee & $\checkmark$ & & \\
\hline Develop stress testing & & $\checkmark$ & \\
\hline Ease or remove the ceilings on lending rates & & & $\checkmark$ \\
\hline Create a single independent Capital Market regulatory authority & & $\checkmark$ & \\
\hline Prohibit insider trading and market manipulation & & $\checkmark$ & \\
\hline Institute a modern insurance supervision framework & & $\checkmark$ & \\
\hline Strengthen procedures for international cooperation in AML/CFT & $\checkmark$ & & \\
\hline Criminalize the financing of terrorism. & & $\checkmark$ & \\
\hline Increase use of marketable instruments in monetary operations & & $\checkmark$ & \\
\hline Implement the Real Time Gross Settlement system & $\checkmark$ & & \\
\hline
\end{tabular}




\section{Box 1. Integration into the Global and Regional Economies}

Kuwait's integration into the global economy has been increasing in recent years. In particular, portfolio investment jumped sharply since 2004-05; the number of expatriate workers in the labor force rose from nearly 1 million in 2000 to 1.7 million in 2007; and trade has been growing steadily as a share of GDP.

\section{Global integration is underpinned by} active membership in global and regional trade initiatives and an ongoing push to liberalize domestic regulations. A member of the WTO since 1995, Kuwait also

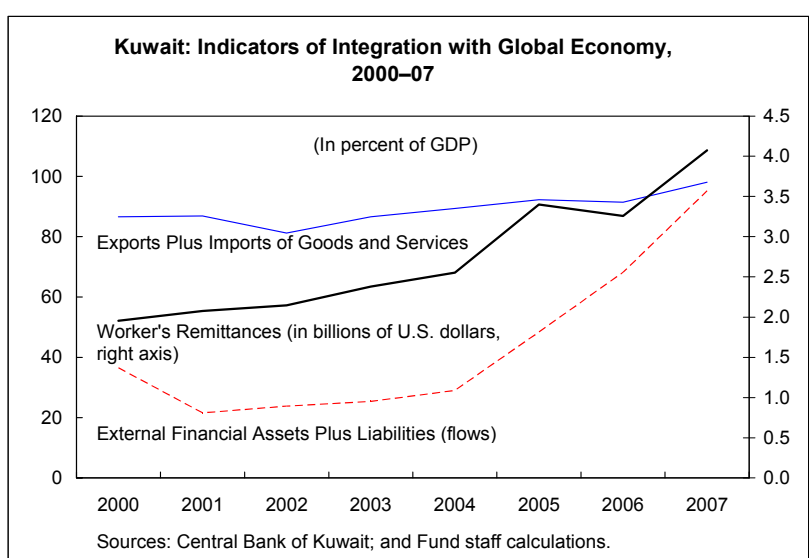

participates in various preferential trade arrangements, including the GCC customs union and the Greater Arab Free Trade Area.

The GCC common market agreement was launched in January 2008. While a common external tariff ( 5 percent) is already in place, ensuring the uniform treatment of GCC nationals across member countries (e.g. residency; private and public sector employment) will require further actions.

The GCC common market is viewed as a precondition to monetary union, planned for 2010. Kuwait has met all convergence criteria as of end-2007. A number of challenges remain toward achieving the monetary union, notably, the creation of a common central bank. Monetary policy frameworks, payment and settlement systems, regulatory and supervisory structures, and other central bank functions are also yet to be fully harmonized.

Free Trade Agreements (FTAs). Following the bilateral FTAs signed by Bahrain and Oman with the U.S., the GCC took the decision to delegate all bilateral FTA negotiations to the GCC Secretariat, except those with the U.S. There are ongoing FTA negotiations between the GCC and MERCOSUR, Australia, China, India, Iran, Japan, Singapore, and Turkey. Negotiations with the European Union (EU) are at an advanced stage; the planned agreement would also cover legal issues, human rights, and political dialogue.

\begin{tabular}{|l|l|l|l|l|l|}
\hline \multicolumn{5}{|c|}{ GCC Countries: Convergence Criteria as of end-2007 1/ } \\
\hline & $\begin{array}{c}\text { Budget deficit } \\
\text { lower than 3 } \\
\text { percent of the } \\
\text { GDP, or } \\
5 \text { percent when } \\
\text { oil prices are } \\
\text { weak }\end{array}$ & $\begin{array}{c}\text { Public debt-to- } \\
\text { GDP ratio lower } \\
\text { than } 60 \text { percent }\end{array}$ & $\begin{array}{c}\text { Foreign } \\
\text { exchange } \\
\text { reserves in } \\
\text { excess of four } \\
\text { months' imports }\end{array}$ & $\begin{array}{c}\text { Interest rates not } \\
\text { higher than two } \\
\text { percentage } \\
\text { points above the } \\
\text { average of the } \\
\text { lowest three } \\
\text { countries' rate } \\
\text { than 2 percent above } \\
\text { the average rate of } \\
\text { the six states 2/ }\end{array}$ & $\checkmark$ \\
Convergence criteria & $\checkmark$ & $\checkmark$ & $\checkmark$ & $\checkmark$ \\
\hline Kuwait & \multicolumn{1}{|c|}{$\checkmark$} & $\checkmark$ & \\
\hline Source: GCC national authorities; and Fund staff estimates. \\
$1 /$ " $\checkmark$ " - criterion has been met. \\
$2 /$ A weighted average based on U.S. dollar nominal GDP of the six states.
\end{tabular}


5. Kuwait has continued a strong tradition of providing financial assistance to poorer countries, and the authorities are considering ways to extend HIPC debt relief to claims held by KIA, compatible with the rules and laws governing its operations.

\section{Medium-Term Policies AND OUtlook}

6. The medium-term outlook remains highly favorable. The projected moderate growth in the oil sector will hinge upon the development of new oil and gas fields. Non-oil GDP is projected to grow at 8 percent - as Kuwait develops its potential as a regional service center and a gateway to Iraq and Iran - spurred by high oil prices, infrastructure spending, and structural reforms to support private investment. Inflation is projected to increase further in 2008 due largely to supply factors before moderating to about 5 percent over the medium term.

7. Both the external current account and fiscal positions are projected to remain in large surplus, albeit at declining levels due to the high import intensity of the planned investment projects and the projected easing in oil prices. While the authorities generally agreed with staff's projections, they noted several downside risks: a possible sharp decline in oil prices; intensified domestic pressures for increasing budgetary transfers; setbacks in the implementation of structural reforms, including due to parliamentary opposition; and shortfalls in the execution of planned public investments.

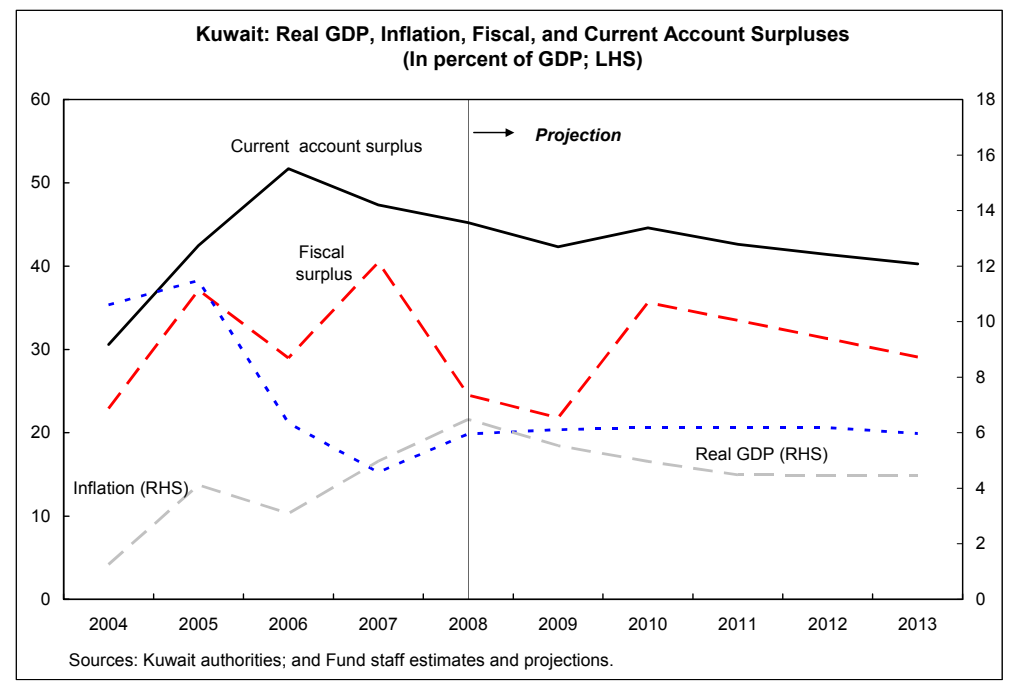

IV. REPORT ON DISCUSSIONS

A. Oil Sector Prospects

8. The authorities reaffirmed that Kuwait would continue to play a constructive role in the oil market by implementing major investment plans for the sector. The authorities plan to increase oil production capacity from the current level of 2.7 million barrel 
per day (mbpd) to $4 \mathrm{mbpd}$ in 2020. Achieving the $4 \mathrm{mbpd}$ level would require developing the northern field ("Project Kuwait") and utilizing advanced technology that may have to be provided by foreign companies. Parliament is currently debating draft legislation with a view to allow participation of foreign companies in developing these fields, perhaps through enhanced technical service agreements. In

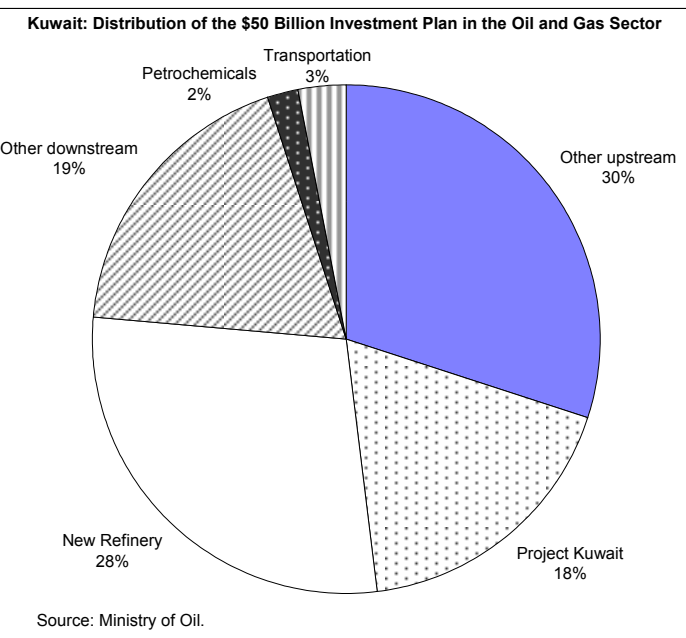

the downstream sector, the authorities plan to double refining capacity to about $1.4 \mathrm{mbpd}$ by 2012-13. Total sectoral investments for 2008-13 would amount to $\$ 50$ billion, to be largely financed internally by Kuwait Petroleum Company (KPC), with strong involvement of the Kuwaiti and foreign private sector in the downstream sector. Most projects are currently in the execution or bid submission stage.

\section{B. Containing Inflationary Pressures}

9. Growth of the nontradables sector, an appropriate fiscal policy framework, and lower credit growth will be critical for containing inflation. Rising oil wealth has boosted demand, including for nontradable items and expatriate labor, pushing up prices for housing, communication, and other services as well as asset prices (notably real estate). Structural reforms to enhance the supply response in the services sector (including better access to land) will be key to reduce pressures on nontradable prices. Fiscal policy should balance the need to spend part of the oil wealth to support consumption and investment, while avoiding fuelling inflation. Excessive increases in salaries and transfers would add to demand pressures and increase the risk of a wage-price spiral. Containing credit growth will also be necessary to restrain demand pressures.

\section{Fiscal Policy Strategy}

10. The authorities are working on building a stronger consensus within parliament around their fiscal strategy of emphasizing higher capital spending to support growth, limiting current expenditure, and saving part of the oil revenues for future generations and to reduce dependency on oil income for funding the budget. Accumulation of financial assets along with investments in infrastructure, education and public services that help create jobs for Kuwaitis in the private sector are likely to be the most effective way to ensure current and future generations benefit from the gains in oil wealth. In the face of strong populist pressures for "sharing the oil wealth", the authorities will try to contain raises in salaries and benefits in the public sector-in particular if not closely tied to performance 
and merit - to contain recurrent expenditures and to avoid weakening the incentives to acquire marketable skills needed for employment in the private sector. Similarly, they are aware that further raising already high subsidies will add to price distortions and the misallocation of resources, notably in the power sector. ${ }^{3}$ Excessive increases in current outlays would also limit the resources that could be saved to insure intergenerational equity and reduce dependency in oil income.

\section{The authorities were skeptical regarding staff suggestions that greater} transparency of KIA and KPISS financial operations could help in strengthening the consensus for their fiscal strategy, or help to forestall steps towards financial protectionism in countries where the growing role of sovereign wealth funds has raised concerns. They stressed that KIA's financial position was already subject to parliamentary scrutiny, ensuring accountability. ${ }^{4}$ Furthermore, KIA's investment policy is purely commercially driven and respects regulations in the financial markets it invests in. The authorities hope that the Fund would play a constructive role in ensuring a positive dialogue between sovereign wealth funds and recipient countries, although they were not yet convinced of the need for a code of "best practices."

\section{The authorities pointed out that many elements of a strong fiscal policy}

framework were already in place, but recognized further reforms are needed. There are clear rules governing transfers to the two government investment funds (RFFG and GRF). The recent consolidation of budget preparation in the ministry of finance constitutes a further strengthening of the fiscal framework. The authorities plan sizable transfers from the budget to close the remaining KPISS actuarial deficit over the next two years and are considering reforming the contribution and benefits rules to ensure viability of the system. Furthermore, the authorities believe that further progress should be made towards improved budget accounting and monitoring, including the adoption of GFSM 2001; and a better anchoring of one-year budgets in rolling medium-term fiscal frameworks.

\section{Monetary and Exchange Rate Policy and Financial Sector Developments}

\section{The authorities see considerable merit in continuing a pegged exchange rate} regime. Underpinned by open trade, capital and labor regimes, it has contributed to decades of macroeconomic stability. The authorities expect it to weather the current tension arising from the non-synchronization between the U.S. and Kuwait business cycles, which has led to the easing of monetary policy in the U.S., while Kuwait is facing an economic boom and

\footnotetext{
${ }^{3}$ In addition, ad-hoc transfers, such as cancelling private debts, as repeatedly discussed in parliament, would be highly inequitable as it could create serious moral hazard in the future.

${ }^{4}$ The data are widely reported in the media, although by law cannot be formally published.
} 
inflationary pressures. The recent move to an undisclosed basket peg should help create some room for maneuver vis-à-vis U.S. monetary policy and better align the peg with Kuwait's trading and investment pattern. Within this constraint, the CBK plans to rely mainly on prudential measures to keep credit expansion under control. The authorities remain committed to join the planned GCC monetary union, but are aware of the urgency to develop very soon with their partners a common framework for exchange rate and monetary policy, and establish the necessary institutions to support this framework, if the target date of 2010 is to be met.

\section{While the banking system is sound, the authorities remain vigilant about}

investment companies. The banking sector is well capitalized and highly profitable (Table 6). The recent global financial turmoil appears not to have affected the financial system. Given the rapid increase in credit and the direct and indirect exposure of Kuwait's banking sector to domestic and international stock and real estate markets, the CBK is monitoring banks closely, including through regular stress testing. The authorities recognize that the number, size and activities of investment companies have grown significantly over the last few years, making that sector systemically important (see Box 2). The authorities are comfortable with the overall current regulatory framework, which covers disclosure, credit concentration and provisioning, anti-money laundering, and consumer/installment loans limits. Moreover, the CBK is carefully watching individual banks' exposures to investment companies. In the CBK's view, most investors in investment companies are high net worth individuals, who should be left to assume risks independently, and there will be no government bail-outs of any investment company.

\section{E. Domestic and External Stability}

\section{In the authorities' view, the current and planned policy mix will lead to} domestic and external stability over the medium term. While there is no generally accepted methodology to assess the level of the exchange rate for oil exporters, it seems reasonable to assume that the large positive terms-of-trade (TOT) shock during 2003-07 appreciated the equilibrium real effective exchange rate (ERER). This is consistent with staff estimates using CGER-type equilibrium exchange rate and macroeconomic balance approaches (see Box 3). Either approach suggests that a moderate undervaluation was caused by the oil price shock, but has been absorbed already or will disappear in the near future. The authorities view both assessment methodologies as ill-suited for oil economies and argued that an appropriate assessment should emphasize the need for ensuring intergenerational equity and reducing dependence on oil revenues. Such an assessment would, in their view, call for high public investments to build physical and human capital as well as continued large fiscal and current account surpluses, possibly larger than currently planned. Finally, the authorities also argued that current account balances were determined mostly by fiscal policy with little role for the exchange rate. Reducing the current account surplus would involve either greater fiscal expansion at the risk of creating higher inflation, 
or reducing oil production, which would undoubtedly affect world oil prices. Furthermore, since Kuwait produces virtually no other tradables but oil, its real exchange rate had in particular little impact on other countries' economies.

\section{Box 2. Investment Companies—Growing by Leaps and Bounds}

\section{High oil revenues, financial liberalization and changing investment patterns have spurred the rapid growth of Kuwait's asset management industry. ${ }^{1}$}

Between 2002 and 2007, the number of investment companies doubled to 78 , with balance sheet assets growing by an annual average rate of 26 percent between 2002-07. Investment funds now manage on- and off-balance sheet assets amounting to about $\$ 160$ billion. With the domestic bond market virtually nonexistent, investment companies have large exposures to domestic and international equity and real estate markets. Their capital-to-asset ratio on average exceeds 35 percent, although the net capital position could be smaller due to cross holdings. Loans from banks averaged 15 percent of

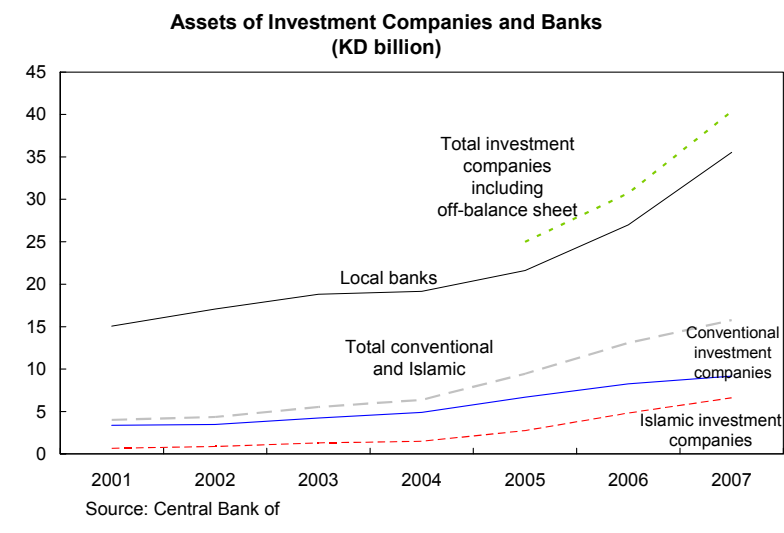
the investment companies total liabilities during 2004-07; foreign lines of credit made up 25 percent of liabilities in 2007.

\section{Investment companies are major players in the local stock exchange and highly sensitive to its} performance. Investment companies accounted for a third of share volume traded in the KSE during 2007, and 16 percent of market capitalization in December 2007. Movements in the investment companies' index have mirrored the broader Kuwait Stock Exchange (KSE) index. At end 2007, the 43 listed investment companies posted on average price-earnings ratio of 7, much lower than bank stocks (18) and the Kuwait market average (12). The large exposure of the investment companies to the KSE was evident from the sensitivity of companies' earning to KSE performance.

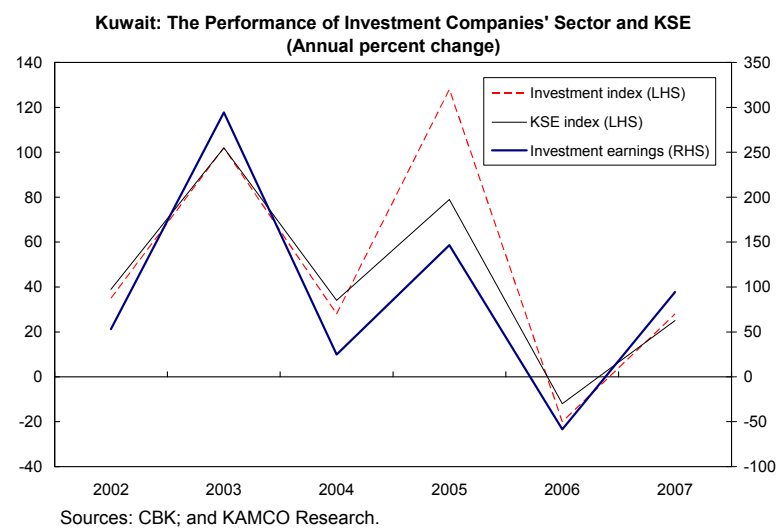

Regulation and supervision are divided among the CBK, KSE and Ministry of Commerce. The central bank's regulatory and supervisory focus aims at facilitating market discipline through dissemination of information in accordance with International Financial Reporting Standards. Lending activities are largely subject to the same prudential rules as bank lending.

${ }^{1}$ The global fund management industry — mutual funds, pension funds and insurance assets — doubled to \$61 trillion during 2002-06. According to the 2007 World Wealth Report by Merrill Lynch and Capgemini, the wealth of individuals in the Middle East with assets over \$1 million is projected to grow from the current level of \$1.4 trillion to \$2.2 trillion by 2011 . 


\section{Box 3. Exchange Rate Assessment for Kuwait}

Staff estimates using the equilibrium real exchange rate (ERER) approach suggest that the KD is currently moderately undervalued. Staff found strong evidence of a long-run cointegration relationship between the KD REER and certain key fundamentals. Specifically, an improvement in the TOT by 10 percent appreciates the ERER by 2 percent; an increase in investment income by 1 percentage point of GDP appreciates the ERER by 0.12 percent; and an increase in government expenditure by 1 percentage point of GDP depreciates the ERER by 0.3 percent. From 2003, when the actual REER was broadly in line with the estimated equilibrium rate, Kuwait's ERER has been on a rising trend driven by a significant improvement in the TOT and investment income and a small decline in government expenditure. The actual REER started to appreciate since 2004, with a gap to the smoothed ERER of 11 percent in 2007. This gap is projected to vanish by 2009 given the projected inflation-driven appreciation of the actual REER, while the equilibrium rate remains unchanged as the expansionary fiscal stance and low investment income offset the projected further improvement in the TOT. Changing the time period underlying the estimation, or replacing the terms of trade with real oil prices or the net oil balance, does not alter the thrust of these findings.

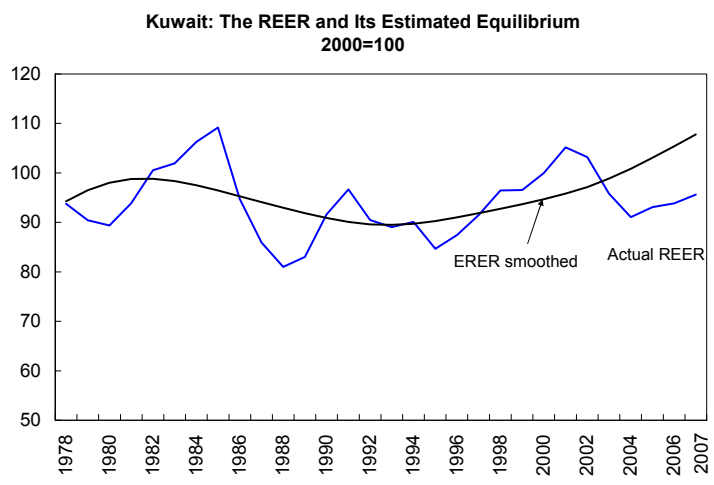

The macroeconomic balance (MB) approach indicates that the current account (CA) is close to its "norm." Similar to one of the CGER-approaches, a panel-estimate using data for the GCC countries finds a significant relationship between CA balances and a set of fundamentals (fiscal balance, population growth, NFA, oil balance, and per capita income). Specifically, a higher fiscal balance, higher initial NFA, and an improvement in the oil balance improve the CA balance. Given the domestic and external stability prevailing historically in the GCC countries, this "norm" is used as the benchmark to gauge external stability. After "overshooting" the norm in 2006, the prevailing CA balance is close to that norm, and this would remain the case in the medium term under the authorities'

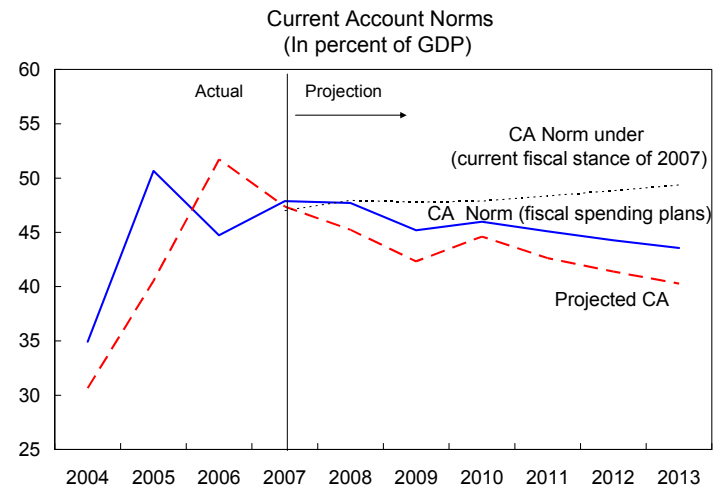
investment program.

\section{F. Structural and Statistical Issues}

\section{Acceleration of structural reforms in other key areas would be vital to support} private sector-led investment and employment generation. While Kuwait ranks relatively high in global assessments of business conditions, procedures for starting a new business are perceived as cumbersome. The authorities are working with parliament on several reforms including: 
- Broadening incentives for involving foreign technical know-how in the development of Kuwait's northern oil fields.

- $\quad$ Providing a comprehensive legal framework to expand the role of the private sector through enacting companies, competition, public-private partnership and privatization laws.

- $\quad$ Approving the Capital Market Law to unify and enhance the regulatory and supervisory framework for the market.

- $\quad$ Enabling further access to land for private business and individuals.

17. Efforts to improve macroeconomic statistics need to continue. While the provision of economic data is adequate for surveillance and has continued to improve, the lack of timely availability of some key data remains an obstacle to economic analysis. In particular, the authorities concur that the recent delay in the production of the CPI needs to be urgently addressed, especially given the importance of current inflationary developments for economic policy. The authorities expressed their intention to continue to improve statistics more generally.

\section{Staff Appraisal}

18. Kuwait's economy had yet another strong performance in 2007, with prudent macroeconomic management supporting high growth in the non-oil economy. Maintaining this performance over the medium term and creating jobs for Kuwaitis in the private sector would require further structural reforms that promote a dynamic private sector driven economy, with public spending focused primarily on infrastructure and education. In the short-run, the main challenge will be to contain inflation, although temporarily higher inflation may be an inevitable part of fiscal spending to increase absorptive capacity.

\section{Kuwait continues to play a constructive role in the global oil market, and} implementation of its ambitious plan to expand production and refining capacity will sustain Kuwait's favorable economic outlook and support global oil market stability. Enhancing the scope for involving foreign technical know-how in the development of Kuwait's northern oil fields will be critical to achieve the plan's production targets and maximize the recovery rate from the new northern fields and currently producing fields.

20. Reducing inflationary pressures requires enhancing the supply response in the nontradable sector, a strong fiscal policy framework, and containing credit growth. While the move to an undisclosed basket peg might help to contain imported inflation, enhancing the supply of nontradables, especially housing and land, will be more important in controlling inflationary pressures. Fiscal expenditure will have to strike a delicate balance between addressing supply bottlenecks (especially in infrastructure and education) while 
avoiding excessive demand pressures. Containing the strong growth in credit to the private sector would help to restrain demand pressures, but the use of interest rates in this regard would involve a trade-off with the need to contain speculative inflows and is in any case constrained by the basket peg.

21. The government's fiscal strategy is key for sustaining high job-creating growth and reducing dependence on oil income over the long run, while preserving domestic and external stability. Staff urges the authorities to resist populist pressures to push up current expenditures by raises in salaries and benefits that are not closely tied to performance and merit. Rather than expanding an inefficient subsidies system, subsidies should be better targeted. The main element of the fiscal strategy should be centered around higher investments in infrastructure, better education and public services, and accumulating additional resources to insure intergenerational equity and reduce dependence on oil. Greater transparency regarding the balance sheets, income, as well as contingent liabilities of KIA and KPISS, should support the fiscal strategy.

22. Staff encourages the authorities to strengthen the fiscal framework further by

(a) complementing plans to close the remaining KPISS actuarial deficit by reforming the contribution and benefits rules so as to ensure viability of the system; (b) better anchoring of one-year budgets in rolling medium-term fiscal frameworks; (c) introducing GFSM 2001 accounting; and (d) furthering the ongoing coordination with other GCC countries toward the introduction of a value-added tax (VAT) and harmonization of tax laws.

\section{Staff considers the pegged exchange rate regime an appropriate choice given} Kuwait's openness, structure of financial markets, and the plans for regional monetary union. In the context of the pegged exchange regime and an easing monetary stance in the U.S., the authorities will need to use available prudential tools and fiscal and structural policies to help contain inflation and credit growth, and limit financial system vulnerabilities. The large growth in the investment companies sector calls for continued vigilance and regular stress testing for the sector. To address weaknesses in financial sector supervision and regulation identified in the FSAP, establishment of a unified and independent capital market regulator applying best practices will be particularly important.

\section{Staff views the current and planned policy mix as contributing to external and} domestic stability. Fiscal policy is key to ensure domestic and external stability, as the role of the real exchange rate in determining the current account is limited. Staff analysis points to a moderate undervaluation of the KD up to around 2006-07. However, it also suggests that the ongoing appreciation of the KD in real effective terms, set to accelerate due to relatively higher inflation in 2008, and the expansionary fiscal stance over the medium term, would bring the exchange rate in line with fundamentals over the course of 2008.

25. Staff urges the authorities to expedite structural reforms aimed at promoting the role of the private sector. Building on recent progress, staff encourages the authorities to 
swiftly bring capital market, companies, competition, public-private partnership and privatization laws in line with best international practice, and to further streamline business registration procedures and reduce administrative barriers to investment. Staff welcomes the authorities' intention to improve public sector statistics and encourages them to develop a program aimed at subscribing to the Fund's Special Data Dissemination System (SDDS).

26. Staff commends the authorities for substantial assistance extended to countries in and outside the region, active support for the HIPC initiative, and for considering ways to extend HIPC debt relief to claims held by KIA.

27. It is recommended that the next Article IV consultation take place on the standard 12-month cycle. 
Table 1. Kuwait: Selected Economic Indicators, 2004-08

(Quota: SDR 1381.1 million)

(Population: 3.18 million, Dec. 2006)

(Per capita GDP: \$32,019, 2006 estimate)

\begin{tabular}{|c|c|c|c|c|c|}
\hline & 2004 & 2005 & $\begin{array}{r}\text { Est. } \\
2006\end{array}$ & $\begin{array}{r}\text { Est. } \\
2007\end{array}$ & $\frac{\text { Proj. }}{2008}$ \\
\hline \multicolumn{6}{|l|}{ Oil and gas sector } \\
\hline Total oil and gas exports (in billions of U.S. dollars) & 27.8 & 44.1 & 55.7 & 59.7 & 81.4 \\
\hline Average oil export price (in U.S. dollar/barrel) & 34.1 & 49.1 & 60.2 & 67.8 & 91.4 \\
\hline \multirow[t]{2}{*}{ Crude oil production (in millions of barrels/day) } & 2.29 & 2.57 & 2.64 & 2.58 & 2.60 \\
\hline & \multicolumn{5}{|c|}{ (Annual percentage change, unless otherwise indicated) } \\
\hline \multicolumn{6}{|l|}{ National accounts and prices } \\
\hline Nominal GDP (market prices, in billions of Kuwaiti dinar) & 17.5 & 23.6 & 28.6 & 31.3 & 39.6 \\
\hline Nominal GDP (market prices, in billions of U.S. dollars) & 59.4 & 80.8 & 98.7 & 111.3 & 145.1 \\
\hline Real GDP (factor cost) & 10.6 & 11.5 & 6.4 & 4.6 & 6.0 \\
\hline Real oil GDP & 8.1 & 11.4 & 2.9 & -2.3 & 1.3 \\
\hline Real non-oil GDP & 12.9 & 12.0 & 9.4 & 9.2 & 8.6 \\
\hline CPI inflation (average) & 1.3 & 4.1 & 3.1 & 5.0 & 6.5 \\
\hline \multirow[t]{2}{*}{ Unemployment rate (Kuwaiti nationals) } & 3.9 & 3.8 & 4.0 & $\ldots$ & $\ldots$ \\
\hline & \multicolumn{5}{|c|}{ (In percent of GDP at market prices) } \\
\hline \multicolumn{6}{|l|}{ Investment and savings } \\
\hline Investment & 18.2 & 16.4 & 15.2 & 20.3 & 21.3 \\
\hline Public & 3.7 & 3.0 & 2.9 & 6.0 & 6.8 \\
\hline Private 1/ & 14.5 & 13.5 & 12.4 & 14.3 & 14.5 \\
\hline Gross national savings & 48.8 & 58.9 & 67.0 & 67.6 & 66.5 \\
\hline Public & 37.8 & 47.3 & 56.4 & 59.3 & 55.9 \\
\hline Private $1 /$ & 11.0 & 11.6 & 10.6 & 8.4 & 10.7 \\
\hline \multirow[t]{2}{*}{ Savings/investment balance } & 30.6 & 42.5 & 51.7 & 47.4 & 45.2 \\
\hline & \multicolumn{5}{|c|}{ (In percent of GDP at market prices) } \\
\hline \multicolumn{6}{|l|}{ Budgetary operations $2 /$} \\
\hline Revenue & 55.7 & 64.5 & 64.0 & 72.6 & 70.3 \\
\hline Oil & 42.9 & 52.1 & 49.5 & 56.6 & 58.0 \\
\hline Non-oil, of which: & 12.8 & 12.4 & 14.5 & 16.0 & 12.3 \\
\hline Investment income & 9.3 & 9.8 & 11.5 & 13.6 & 10.2 \\
\hline Expenditures and net lending & 32.8 & 27.4 & 35.0 & 32.2 & 45.8 \\
\hline Current 3/ & 28.6 & 23.8 & 30.9 & 24.7 & 37.8 \\
\hline Capital & 4.2 & 3.6 & 4.2 & 7.4 & 7.9 \\
\hline Balance & 22.9 & 37.1 & 29.0 & 40.5 & 24.5 \\
\hline Domestic financing & -5.7 & -1.2 & -2.8 & -3.2 & -2.4 \\
\hline External financing & -17.3 & -35.9 & -26.1 & -37.2 & -22.1 \\
\hline Non-oil primary balance (in percent of non-oil GDP) & -51.6 & -48.2 & -66.3 & -58.4 & -95.5 \\
\hline \multirow[t]{2}{*}{ Total gross debt (calendar year-end) } & 17.3 & 11.8 & 8.5 & 7.0 & 5.5 \\
\hline & \multicolumn{5}{|c|}{ (Changes in percent of beginning broad money stock) } \\
\hline \multicolumn{6}{|l|}{ Money and credit } \\
\hline Net foreign assets $4 /$ & 10.3 & 3.2 & 12.5 & 1.1 & 7.6 \\
\hline Net domestic assets & 1.8 & 9.1 & 9.1 & 18.2 & 6.7 \\
\hline Claims on government (net) & -10.4 & -2.6 & -6.4 & -6.8 & -5.1 \\
\hline Claims on nongovernment sector & 14.5 & 17.6 & 24.5 & 35.6 & 21.3 \\
\hline Broad money & 12.1 & 12.3 & 21.7 & 19.3 & 14.3 \\
\hline Kuwaiti dinar 3-month deposit rate (year average; in percent) & 1.6 & 2.9 & 5.0 & 5.2 & $\ldots$ \\
\hline \multirow[t]{2}{*}{ Stock market unweighted index (annual percent change) } & 33.8 & 78.6 & -12.0 & 25.0 & $\ldots$ \\
\hline & & ns of $U$. & ars, unle & nerwise i & ed) \\
\hline External sector & & & & & \\
\hline Exports of goods & 30.1 & 47.0 & 58.6 & 62.8 & 84.7 \\
\hline Of which: Non-oil exports & 2.3 & 2.9 & 3.0 & 3.1 & 3.3 \\
\hline Annual percentage change & 4.6 & 23.0 & 4.0 & 5.5 & 5.0 \\
\hline Imports of goods & -11.7 & -14.2 & -14.3 & -16.7 & -19.9 \\
\hline Annual percentage change & 18.1 & 22.1 & 0.6 & 16.5 & 19.0 \\
\hline Current account & 18.2 & 34.3 & 51.1 & 52.7 & 65.6 \\
\hline In percent of GDP & 30.6 & 42.5 & 51.7 & 47.4 & 45.2 \\
\hline External public and publicly guaranteed debt & 0.7 & 1.8 & & $\ldots$ & \\
\hline International reserve assets & 8.3 & 9.0 & 12.6 & 15.5 & 18.6 \\
\hline In months of imports of goods and services & 5.2 & 4.7 & 6.1 & 5.5 & 5.7 \\
\hline & & rcentag & ge; unle & erwise $n$ & \\
\hline Memorandum items: & & & & & \\
\hline Exchange rate (U.S. dollar per KD, period average) & 3.39 & 3.42 & 3.45 & 3.56 & $\ldots$ \\
\hline Nominal effective exchange rate (NEER) & -3.9 & 0.4 & 0.5 & -0.6 & $\ldots$ \\
\hline Real effective exchange rate (REER) & -5.1 & 2.1 & 0.8 & 1.9 & $\ldots$ \\
\hline Sovereign rating (S\&P) & $A+$ & $A+$ & $A+$ & AA- & $\ldots$ \\
\hline
\end{tabular}

Sources: Data provided by the authorities; and Fund staff estimates and projections.

1/ Also includes government entities.

2/ Kuwaiti fiscal year ending March 31, e.g. 2007 refers to fiscal year 2007/2008.

3/ In 2006/07 KD 2 billion was transferred to partly cover the actuarial deficit of the Public Pension Fund. In 2008/09 KD 5.5 billion

(6.8 percent of GDP) is budgeted.

4/ Excludes SDRs and IMF reserve position. 
Table 2. Kuwait: Summary of Government Finance, 2004/05-2008/09 1/

\begin{tabular}{|c|c|c|c|c|c|c|c|}
\hline & $2004 / 05$ & $\begin{array}{r}\text { Prel. } \\
005 / 06\end{array}$ & $\begin{array}{r}\text { Budget } \\
2006 / 07\end{array}$ & $\begin{array}{l}\text { Prel. } \\
06 / 07\end{array}$ & $\begin{array}{l}\text { Budget } \\
2007 / 08\end{array}$ & $\begin{array}{r}\text { Proj. } \\
2007 / 08\end{array}$ & $\begin{array}{r}\text { Proj. } \\
2008 / 09\end{array}$ \\
\hline & \multicolumn{7}{|c|}{ (In billions of KD) } \\
\hline Total revenue & 10.6 & 16.0 & 8.3 & 18.8 & 8.1 & 24.2 & 28.2 \\
\hline Oil and gas & 8.2 & 13.0 & 7.7 & 14.5 & 7.5 & 18.9 & 23.3 \\
\hline \multicolumn{8}{|l|}{ Investment income and transfer of profits of } \\
\hline Other current revenue $3 /$ & 0.6 & 0.6 & 0.6 & 0.9 & 0.7 & 0.8 & 0.8 \\
\hline Capital revenue & 0.1 & 0.0 & 0.0 & 0.0 & 0.0 & 0.0 & 0.0 \\
\hline Total expenditure & 6.2 & 6.8 & 10.5 & 10.3 & 11.1 & 10.7 & 18.4 \\
\hline Current & 5.4 & 5.9 & 8.9 & 9.0 & 8.5 & 8.3 & 15.2 \\
\hline Current excluding recapitalization of social security & 5.4 & 5.9 & 6.9 & 7.0 & 8.5 & 8.3 & 10.4 \\
\hline Wages and salaries & 1.9 & 2.1 & 2.5 & 2.5 & 3.0 & 2.7 & 3.2 \\
\hline Goods and services & 1.4 & 1.4 & 1.6 & 1.6 & 1.9 & 1.7 & 2.1 \\
\hline Interest on domestic debt 4/ & 0.1 & 0.1 & 0.0 & 0.1 & 0.0 & 0.1 & 0.1 \\
\hline Transfers abroad & 0.1 & 0.2 & 0.2 & 0.2 & 0.4 & 0.4 & 0.4 \\
\hline Subsidies and transfers $5 / 6 /$ & 1.9 & 2.1 & 2.6 & 2.7 & 3.2 & 3.4 & 3.9 \\
\hline Recapitalization of social security & 0.0 & 0.0 & 2.0 & 2.0 & 0.0 & 0.0 & 5.5 \\
\hline Capital & 0.8 & 0.9 & 1.6 & 1.2 & 2.6 & 2.5 & 3.2 \\
\hline Overall balance & 4.4 & 9.2 & -2.2 & 8.5 & -3.0 & 13.5 & 9.8 \\
\hline Overall balance exc. oil rev. & -3.8 & -3.7 & -9.9 & -6.0 & -10.4 & -5.4 & -13.4 \\
\hline Overall balance exc. oil rev. and inv. income & -5.6 & -6.2 & -9.9 & -9.4 & -10.4 & -9.9 & -17.5 \\
\hline Financing & -4.4 & -9.2 & 2.2 & -8.5 & 3.0 & -13.5 & -9.8 \\
\hline Domestic (net) & -1.1 & -0.3 & $\ldots$ & -0.8 & $\ldots$ & -1.1 & -1.0 \\
\hline Banks & -1.1 & -0.3 & $\ldots$ & -0.8 & $\ldots$ & -1.1 & -1.0 \\
\hline Nonbanks & 0.0 & 0.0 & $\ldots$ & 0.0 & $\ldots$ & 0.0 & 0.0 \\
\hline External & 0.0 & 0.0 & $\ldots$ & 0.0 & $\ldots$ & 0.0 & 0.0 \\
\hline \multirow[t]{2}{*}{ Reserve funds $7 /$} & -3.3 & -8.9 & $\ldots$ & -7.7 & $\ldots$ & -12.4 & -8.9 \\
\hline & \multicolumn{7}{|c|}{ (In percent of GDP) } \\
\hline Revenue & 55.7 & 64.5 & 28.3 & 64.0 & 24.3 & 72.6 & 70.3 \\
\hline Oil and gas & 42.9 & 52.1 & 26.4 & 49.5 & 22.3 & 56.6 & 58.0 \\
\hline Investment income & 9.3 & 9.8 & 0.0 & 11.5 & 0.0 & 13.6 & 10.2 \\
\hline Other current revenue $3 /$ & 3.1 & 2.5 & 1.9 & 2.9 & 2.0 & 2.3 & 2.0 \\
\hline Expenditure & 32.8 & 27.4 & 35.7 & 35.0 & 33.3 & 32.2 & 45.8 \\
\hline Current & 28.6 & 23.8 & 30.2 & 30.9 & 25.4 & 24.7 & 37.8 \\
\hline Current excluding recapitalization of social security & 28.6 & 23.8 & 23.4 & 24.0 & 25.4 & 24.7 & 24.2 \\
\hline Wages and salaries & 10.2 & 8.5 & 8.5 & 8.4 & 8.9 & 8.1 & 7.9 \\
\hline Goods and noninterest services & 7.5 & 5.8 & 5.4 & 5.4 & 5.7 & 5.2 & 5.3 \\
\hline Interest on domestic and foreign debt & 0.4 & 0.4 & $\ldots$ & 0.3 & $\ldots$ & 0.2 & 0.2 \\
\hline Subsidies and transfers & 9.8 & 8.3 & 8.8 & 9.2 & 9.5 & 10.1 & 9.7 \\
\hline Recapitalization of social security & 0.0 & 0.0 & 6.8 & 6.8 & 0.0 & 0.0 & 13.6 \\
\hline Capital & 4.2 & 3.6 & 5.5 & 4.2 & 7.8 & 7.4 & 7.9 \\
\hline Overall balance & 22.9 & 37.1 & -7.4 & 29.0 & -9.0 & 40.5 & 24.5 \\
\hline Non-oil deficit/Non-oil GDP & -41.1 & -34.7 & -80.0 & -48.6 & -72.8 & -37.6 & -82.4 \\
\hline $\begin{array}{l}\text { Non-oil primary deficit/Non-oil GDP 8/ } \\
\text { Non-oil primary deficit/Non-oil GDP excluding }\end{array}$ & -51.6 & -48.2 & $\cdots$ & -66.3 & $\cdots$ & -58.4 & -95.5 \\
\hline $\begin{array}{l}\text { recapitalization of social security } \\
\text { Memorandum items: }\end{array}$ & -51.6 & -48.2 & $\cdots$ & -50.2 & $\cdots$ & -58.4 & -62.0 \\
\hline Average oil export price (in U.S. dollar/barrel) & 37.8 & 51.8 & 36.0 & 62.1 & 36.0 & 73.7 & 91.2 \\
\hline
\end{tabular}

Sources: Ministry of Finance; Central Bank of Kuwait; and Fund staff estimates and projections.

1/ Coverage of budgetary operations includes the operation of the KIA. Data are on an accrual basis.

2/ Excluded from the national budget presentation. Estimated by Fund staff.

3 / Excludes revenues from utility tariffs (which are included in the national budget presentation), but includes UN (Iraq) compensations.

4/ Covers interest payments on the treasury bills and bonds, and on the DCP bonds. Only the latter is included in the national budget presentation.

5 / In 2006/07 KD 2 billion was transferred to partly cover the actuarial deficit of the social security fund. In 2008/09 $\mathrm{KD} 5.5$ billion is budgeted.

6/ The 2006/07 budget reflects KD 195 million on account of a KD 200 one off grant transfer to each Kuwaiti citizen.

7/ The Reserve Fund for Future Generations (RFFG) and the General Reserve Fund (GRF).

$8 /$ Non-oil primary deficit is defined as total revenues excluding oil revenues and KIA investment income minus non-interest expenditures. 
Table 3. Kuwait: Summary Balance of Payments, 2004-13

\begin{tabular}{|c|c|c|c|c|c|c|c|c|c|c|}
\hline & & & Prel. & Prel. & & & Proj. & & & \\
\hline & 2004 & 2005 & 2006 & 2007 & 2008 & 2009 & 2010 & 2011 & 2012 & 2013 \\
\hline & & & & & billions & U.S. d & ars) & & & \\
\hline Current account & 18.2 & 34.3 & 51.1 & 52.7 & 65.6 & 64.7 & 71.9 & 73.0 & 75.2 & 78.0 \\
\hline Goods (trade balance) & 18.4 & 32.7 & 44.3 & 46.1 & 64.8 & 61.9 & 59.7 & 58.1 & 56.2 & 54.8 \\
\hline Exports & 30.1 & 47.0 & 58.6 & 62.8 & 84.7 & 85.2 & 85.6 & 87.1 & 88.1 & 89.7 \\
\hline Oil exports & 27.8 & 44.1 & 55.7 & 59.7 & 81.4 & 81.7 & 82.0 & 83.3 & 84.1 & 85.5 \\
\hline Non-oil exports including re-exports $1 /$ & 2.3 & 2.9 & 3.0 & 3.1 & 3.3 & 3.5 & 3.6 & 3.8 & 4.0 & 4.2 \\
\hline Of which: re-exports & 0.5 & 0.6 & 0.6 & $\ldots$ & $\ldots$ & $\ldots$ & $\ldots$ & $\ldots$ & $\ldots$ & $\ldots$ \\
\hline Imports & -11.7 & -14.2 & -14.3 & -16.7 & -19.9 & -23.2 & -26.0 & -29.0 & -31.9 & -34.9 \\
\hline Services & -3.8 & -3.9 & -3.2 & -4.9 & -6.0 & -7.0 & -7.7 & -8.5 & -9.2 & -10.0 \\
\hline Transportation & -0.6 & -0.6 & -0.5 & -0.5 & -0.7 & -1.3 & -1.8 & -2.3 & -2.8 & -3.3 \\
\hline Insurance & 0.0 & 0.0 & -0.1 & -0.1 & -0.1 & -0.1 & -0.1 & -0.2 & -0.2 & -0.2 \\
\hline Travel & -3.5 & -4.1 & -5.0 & -5.6 & -6.6 & -7.1 & -7.5 & -8.0 & -8.4 & -8.9 \\
\hline Other services & 0.3 & 0.9 & 2.4 & 1.3 & 1.3 & 1.5 & 1.7 & 2.0 & 2.2 & 2.5 \\
\hline Investment income & 6.1 & 8.9 & 13.3 & 15.6 & 11.7 & 15.6 & 27.0 & 31.8 & 38.2 & 45.2 \\
\hline Receipts & 6.6 & 9.4 & 14.7 & 17.8 & 13.1 & 17.2 & 29.5 & 34.4 & 40.9 & 47.9 \\
\hline General government 2/ & 5.2 & 6.5 & 9.4 & 10.9 & 8.1 & 10.8 & 18.5 & 21.5 & 25.6 & 30.0 \\
\hline Other sectors $3 /$ & 1.4 & 2.9 & 5.3 & 6.9 & 4.9 & 6.4 & 11.1 & 12.9 & 15.3 & 17.9 \\
\hline Payments & -0.5 & -0.6 & -1.4 & -2.2 & -1.4 & -1.6 & -2.6 & -2.7 & -2.7 & -2.7 \\
\hline General government & 0.0 & 0.0 & 0.0 & 0.0 & 0.0 & 0.0 & 0.0 & 0.0 & 0.0 & 0.0 \\
\hline Other & -0.4 & -0.5 & -1.4 & -2.2 & -1.4 & -1.6 & -2.5 & -2.7 & -2.7 & -2.7 \\
\hline Current transfers & -2.6 & -3.4 & -3.3 & -4.1 & -4.8 & -5.8 & -7.0 & -8.3 & -10.0 & -12.0 \\
\hline Capital and financial account & -16.4 & -30.4 & -47.0 & -52.1 & -62.5 & -61.9 & -69.5 & -70.7 & -73.1 & -76.0 \\
\hline Capital account 4/ & 0.4 & 0.8 & 0.9 & 1.2 & 1.2 & 1.2 & 1.2 & 1.2 & 1.2 & 1.2 \\
\hline Financial account & -16.8 & -31.2 & -47.9 & -53.3 & -63.8 & -63.1 & -70.7 & -71.9 & -74.4 & -77.2 \\
\hline Direct investment & -2.5 & -4.9 & -7.8 & -10.3 & -12.6 & -8.8 & -10.5 & -19.2 & -22.7 & -28.0 \\
\hline Abroad & -2.5 & -5.1 & -8.0 & -10.4 & -12.7 & -9.0 & -10.6 & -19.3 & -22.8 & -28.1 \\
\hline In Kuwait & 0.0 & 0.3 & 0.1 & 0.1 & 0.1 & 0.1 & 0.1 & 0.1 & 0.1 & 0.1 \\
\hline Portfolio investment & -13.9 & -10.5 & -25.7 & -37.3 & -36.6 & -35.4 & -31.2 & -24.2 & -18.7 & -16.0 \\
\hline Other investment (net) & -0.4 & -15.7 & -14.4 & -5.7 & -14.6 & -18.9 & -29.0 & -28.5 & -32.9 & -33.3 \\
\hline Net errors and omissions 5/ & -1.0 & -3.3 & -0.4 & 2.7 & 0.0 & 0.0 & 0.0 & 0.0 & 0.0 & 0.0 \\
\hline Overall balance & 0.8 & 0.6 & 3.6 & 3.3 & 3.1 & 2.8 & 2.5 & 2.4 & 2.1 & 2.0 \\
\hline & & & & & In perce & th of $\mathrm{GL}$ & & & & \\
\hline Memorandum items & & & & & & & & & & \\
\hline Current account/GDP (in percent) & 30.6 & 42.5 & 51.7 & 47.4 & 45.2 & 42.3 & 44.6 & 42.6 & 41.4 & 40.3 \\
\hline Current account (excl. oil)/GDP (in percent) & -16.2 & -12.1 & -4.7 & -6.3 & -10.9 & -11.1 & -6.3 & -6.0 & -4.9 & -3.8 \\
\hline Investment income/GDP (in percent) & 10.3 & 11.0 & 13.4 & 14.0 & 8.0 & 10.2 & 16.7 & 18.5 & 21.0 & 23.3 \\
\hline WEO oil price (dollars per barrel) & 37.8 & 53.4 & 64.3 & 71.0 & 95.5 & 94.5 & 93.3 & 92.8 & 92.5 & 92.5 \\
\hline Import growth (in percent) & -99.9 & 22.1 & 0.6 & 16.5 & 19.0 & 16.9 & 11.9 & 11.7 & 9.9 & 9.5 \\
\hline International reserve assets (in millions of U.S. dollars) 6/ & 8.3 & 9.0 & 12.6 & 15.5 & 18.6 & 21.5 & 23.9 & 26.3 & 28.4 & 30.4 \\
\hline In months of imports of goods and services & 5.2 & 4.7 & 6.1 & 5.5 & 5.7 & 5.9 & 6.0 & 6.0 & 6.0 & 6.0 \\
\hline
\end{tabular}

Sources: Central Bank of Kuwait; and Fund staff estimates.

$1 /$ Also includes unrecorded oil exports.

2/ Kuwait Investment Authority, Kuwait Petroleum Corporation, Kuwait Fund for Arab Economic Development, Public Institute for Social Security,

Kuwait Airways Corporation, and Bank of Savings and Credit.

3/ CBK, local banks, investment companies, exchange companies, insurance companies, and the nonfinancial private sector.

4/ Includes UN war compensation.

5/ Includes other unclassified private sector flows.

$6 /$ Includes SDRs and IMF reserve position. 
Table 4. Kuwait: Monetary Survey, 2003-08

\begin{tabular}{|c|c|c|c|c|c|c|}
\hline End of period & 2003 & 2004 & 2005 & 2006 & $\frac{\text { Prel. }}{2007}$ & $\frac{\text { Proj. }}{2008}$ \\
\hline & \multicolumn{6}{|c|}{ (In millions of KD) } \\
\hline Foreign assets (net) $1 /$ & 2,464 & 3,535 & 3,904 & 5,545 & 5,718 & 7,155 \\
\hline Central bank & 1,966 & 2,165 & 2,370 & 3,416 & 4,327 & 5,176 \\
\hline Local banks & 497 & 1,370 & 1,534 & 2,129 & 1,392 & 1,980 \\
\hline Domestic assets (net) & 7,938 & 8,120 & 9,182 & 10,375 & 13,269 & 14,539 \\
\hline Claims on government (net) & 2,323 & 1,246 & 948 & 113 & -968 & $-1,936$ \\
\hline Central bank (net) & -413 & -662 & -520 & -617 & -920 & -809 \\
\hline Claims & 0 & 0 & 15 & 0 & 0 & 0 \\
\hline Deposits & 413 & 662 & 534 & 617 & 920 & 809 \\
\hline Local banks (net) & 2,735 & 1,908 & 1,467 & 731 & -47 & $-1,127$ \\
\hline Claims & 3,051 & 2,750 & 2,463 & 2,165 & 1,912 & 1,912 \\
\hline Government debt bonds & 818 & 604 & 378 & 176 & 0 & 0 \\
\hline Public debt instruments & 2,232 & 2,146 & 2,085 & 1,989 & 1,912 & 1,912 \\
\hline Other claims & 0 & 0 & 0 & 0 & 0 & 0 \\
\hline Deposits & 315 & 842 & 996 & 1,434 & 1,959 & 3,039 \\
\hline Claims on nongovernment sector & 9,379 & 10,886 & 12,937 & 16,148 & 21,822 & 25,873 \\
\hline Credit facilities & 8,419 & 9,867 & 11,827 & 14,934 & 20,139 & 23,816 \\
\hline Local investments & 959 & 1,019 & 1,109 & 1,215 & 1,683 & 2,057 \\
\hline Other items (net) & $-3,764$ & $-4,011$ & $-4,702$ & $-5,886$ & $-7,585$ & $-9,398$ \\
\hline Broad money 2/ & 10,401 & 11,655 & 13,086 & 15,921 & 18,987 & 21,695 \\
\hline Money & 2,612 & 3,174 & 3,727 & 3,550 & 4,147 & 4,738 \\
\hline Quasi money & 7,790 & 8,481 & 9,359 & 12,370 & 14,841 & 17,778 \\
\hline \multirow[t]{2}{*}{ Of which: Foreign currency deposits } & 991 & 1,169 & 1,548 & 2,245 & 1,710 & 2,125 \\
\hline & \multicolumn{6}{|c|}{ (Annual percentage change) } \\
\hline Foreign assets (net) & -15.9 & 43.5 & 10.4 & 42.0 & 3.1 & 25.1 \\
\hline Central Bank & -22.0 & 10.1 & 9.5 & 44.1 & 26.6 & 19.6 \\
\hline Local banks & 21.5 & 175.4 & 12.0 & 38.8 & -34.6 & 42.3 \\
\hline Domestic assets (net) & 18.2 & 2.3 & 13.1 & 13.0 & 27.9 & 9.6 \\
\hline Claims on Government (net) & -10.5 & -46.4 & -24.0 & -88.0 & -953.4 & -100.1 \\
\hline Claims on nongovernment sector & 21.4 & 16.1 & 18.8 & 24.8 & 35.1 & 18.6 \\
\hline Other items (net) & -4.5 & -6.6 & -17.2 & -25.2 & -28.9 & -23.9 \\
\hline Broad money & 7.8 & 12.1 & 12.3 & 21.7 & 19.3 & 14.3 \\
\hline Money & 26.4 & 21.6 & 17.4 & -4.8 & 16.8 & 14.3 \\
\hline Quasi money & 2.8 & 8.9 & 10.4 & 32.2 & 20.0 & 19.8 \\
\hline \multirow[t]{2}{*}{ Of which: Foreign currency deposits } & 9.6 & 18.0 & 32.4 & 45.0 & -23.8 & 24.3 \\
\hline & \multicolumn{6}{|c|}{ (Change in percent of beginning of period broad money stock) } \\
\hline Foreign assets (net) & -4.8 & 10.3 & 3.2 & 12.5 & 1.1 & 7.6 \\
\hline Central bank & -5.7 & 1.9 & 1.8 & 8.0 & 5.7 & 4.5 \\
\hline Local banks & 0.9 & 8.4 & 1.4 & 4.5 & -4.6 & 3.1 \\
\hline Domestic assets (net) & 12.7 & 1.8 & 9.1 & 9.1 & 18.2 & 6.7 \\
\hline Claims on government (net) & -2.8 & -10.4 & -2.6 & -6.4 & -6.8 & -5.1 \\
\hline Claims on nongovernment sector & 17.2 & 14.5 & 17.6 & 24.5 & 35.6 & 21.3 \\
\hline Other items (net) & -1.7 & -2.4 & -5.9 & -9.0 & -10.7 & -9.5 \\
\hline Broad money & 7.8 & 12.1 & 12.3 & 21.7 & 19.3 & 14.3 \\
\hline Money & 5.6 & 5.4 & 4.7 & -1.4 & 3.7 & 3.1 \\
\hline Quasi money & 2.2 & 6.6 & 7.5 & 23.0 & 15.5 & 15.5 \\
\hline Of which: Foreign currency deposits & 0.9 & 1.7 & 3.3 & 5.3 & -3.4 & 2.2 \\
\hline Memorandum items: & \multicolumn{6}{|c|}{ (In percent) } \\
\hline Non-oil GDP/M2 & 75.8 & 76.2 & 79.4 & 74.7 & 73.0 & 73.0 \\
\hline Foreign currency deposits/M2 & 9.5 & 10.0 & 11.8 & 14.1 & 9.0 & 9.8 \\
\hline Private credit/non-oil GDP & 112.2 & 115.2 & 114.8 & 123.9 & 144.5 & 150.5 \\
\hline
\end{tabular}

Sources: Central Bank of Kuwait; and Fund staff estimates.

1/ Excludes SDRs and IMF reserve position.

2/ Excludes deposits with financial institutions which are marginal. For 2007, it was KD 26.1 million. 
Table 5. Kuwait: Illustrative Macroeconomic Baseline Scenario, 2004-13

\begin{tabular}{|c|c|c|c|c|c|c|c|c|c|c|}
\hline & \multicolumn{6}{|c|}{ Est. } & \multicolumn{2}{|c|}{ Baseline } & \multirow[b]{2}{*}{2012} & \multirow[b]{2}{*}{2013} \\
\hline & 2004 & 2005 & 2006 & 2007 & 2008 & 2009 & 2010 & 2011 & & \\
\hline & \multicolumn{10}{|c|}{ (Percentage change, unless otherwise specified) } \\
\hline \multicolumn{11}{|l|}{ Production and prices } \\
\hline Nominal GDP (KD billions) & 17.5 & 23.6 & 28.6 & 31.3 & 39.6 & 41.7 & 44.0 & 46.8 & 49.6 & 52.9 \\
\hline Nominal GDP & 22.8 & 34.8 & 21.4 & 9.1 & 26.7 & 5.4 & 5.4 & 6.3 & 6.1 & 6.6 \\
\hline Nominal non-oil GDP & 12.7 & 17.0 & 14.4 & 16.5 & 14.3 & 12.7 & 12.0 & 11.8 & 11.5 & 11.4 \\
\hline Real GDP & 10.6 & 11.5 & 6.4 & 4.6 & 6.0 & 6.1 & 6.2 & 6.2 & 6.2 & 6.0 \\
\hline Real oil GDP & 8.1 & 11.4 & 2.9 & -2.3 & 1.3 & 1.7 & 2.0 & 2.0 & 2.3 & 1.7 \\
\hline Real non-oil GDP & 12.9 & 12.0 & 9.4 & 9.2 & 8.6 & 8.4 & 8.2 & 8.1 & 7.9 & 7.7 \\
\hline Kuwait crude export price (U.S. dollars per barrel) & 34.1 & 49.1 & 60.2 & 67.8 & 91.4 & 90.4 & 89.0 & 88.8 & 87.8 & 86.0 \\
\hline Crude oil output (millions of barrels per day) & 2.29 & 2.57 & 2.64 & 2.58 & 2.60 & 2.65 & 2.71 & 2.76 & 2.82 & 2.87 \\
\hline Consumer price index & 1.3 & 4.1 & 3.1 & 5.0 & 6.5 & 5.5 & 5.0 & 4.5 & 4.5 & 4.5 \\
\hline & \multicolumn{10}{|c|}{ (Percent of GDP, unless otherwise specified) } \\
\hline Public finance 1/ & & & & & & & & & & \\
\hline Revenue, of which: & 55.7 & 64.5 & 64.0 & 72.6 & 70.3 & 68.6 & 70.5 & 69.1 & 67.6 & 66.0 \\
\hline Oil and gas & 42.9 & 52.1 & 49.5 & 56.6 & 58.0 & 55.4 & 52.9 & 50.5 & 47.8 & 45.0 \\
\hline Investment income 2/ & 9.3 & 9.8 & 11.5 & 13.6 & 10.2 & 11.0 & 15.4 & 16.3 & 17.5 & 18.7 \\
\hline Expenditure & 32.8 & 27.4 & 35.0 & 32.2 & 45.8 & 46.9 & 34.8 & 35.6 & 36.3 & 36.9 \\
\hline Current & 28.6 & 23.8 & 30.9 & 24.7 & 37.8 & 37.5 & 24.9 & 25.1 & 25.3 & 25.4 \\
\hline Capital & 4.2 & 3.6 & 4.2 & 7.4 & 7.9 & 9.4 & 9.9 & 10.4 & 11.0 & 11.4 \\
\hline Fiscal balance (deficit -) & 22.9 & 37.1 & 29.0 & 40.5 & 24.5 & 21.8 & 35.6 & 33.5 & 31.3 & 29.1 \\
\hline Fiscal balance excl. inv. income (deficit -) & 13.6 & 27.3 & 17.5 & 26.8 & 14.4 & 10.7 & 20.3 & 17.2 & 13.8 & 10.4 \\
\hline \multirow[t]{2}{*}{ Non-oil primary deficit/Non-oil GDP (in percent) 3/ } & -51.6 & -48.2 & -66.3 & -58.4 & -95.5 & -93.1 & -61.7 & -60.5 & -59.6 & -58.5 \\
\hline & \multicolumn{10}{|c|}{ (Change in percent of beginning of period broad money stock) } \\
\hline \multicolumn{11}{|l|}{ Money and credit } \\
\hline Foreign assets (net) & 10.3 & 3.2 & 12.5 & 1.1 & 7.6 & 6.4 & 5.7 & 5.5 & 5.2 & 5.2 \\
\hline Domestic assets (net) & 1.8 & 9.1 & 9.1 & 18.2 & 6.7 & 6.3 & 6.3 & 6.2 & 6.3 & 6.2 \\
\hline Claims on government (net) & -10.4 & -2.6 & -6.4 & -6.8 & -5.1 & -0.2 & -1.0 & -0.8 & -0.5 & -0.8 \\
\hline Claims on nongovernment sector & 14.5 & 17.6 & 24.5 & 35.6 & 21.3 & 17.7 & 17.2 & 17.3 & 16.9 & 16.8 \\
\hline \multirow[t]{2}{*}{ Broad money } & 12.1 & 12.3 & 21.7 & 19.3 & 14.3 & 12.7 & 12.0 & 11.8 & 11.5 & 11.4 \\
\hline & \multicolumn{10}{|c|}{ (Percent change, unless otherwise specified) } \\
\hline \multicolumn{11}{|l|}{ Exchange rates } \\
\hline Exchange rates (U.S. dollar per KD, period average) & 3.39 & 3.42 & 3.45 & 3.56 & $\ldots$ & $\ldots$ & $\ldots$ & $\ldots$ & $\ldots$ & $\ldots$ \\
\hline Nominal effective exchange rate & -3.9 & 0.4 & 0.5 & -0.6 & $\ldots$ & $\ldots$ & $\ldots$ & $\ldots$ & $\ldots$ & $\ldots$ \\
\hline Real effective exchange rate & -5.1 & 2.1 & 0.8 & 1.9 & $\ldots$ & $\ldots$ & $\ldots$ & $\ldots$ & $\ldots$ & $\ldots$ \\
\hline & \multicolumn{10}{|c|}{ (Percent of GDP, unless otherwise specified) } \\
\hline \multicolumn{11}{|l|}{ Balance of payments $4 /$} \\
\hline Exports of goods and services excl. re-exports & 54.3 & 61.4 & 64.3 & 65.1 & 65.4 & 62.7 & 61.9 & 59.5 & 57.0 & 54.6 \\
\hline Of which: oil and refined products & 46.7 & 54.6 & 56.4 & 53.6 & 56.1 & 53.4 & 50.9 & 48.6 & 46.3 & 44.1 \\
\hline Imports of goods and services excl. re-exports & -29.7 & -25.7 & -22.7 & -28.1 & -24.9 & -26.7 & -29.7 & -30.5 & -31.1 & -31.5 \\
\hline Investment income (net) & 10.3 & 11.0 & 13.4 & 14.0 & 8.0 & 10.2 & 16.7 & 18.5 & 21.0 & 23.3 \\
\hline Current account & 30.6 & 42.5 & 51.7 & 47.4 & 45.2 & 42.3 & 44.6 & 42.6 & 41.4 & 40.3 \\
\hline Current account (excluding oil exports) & -16.2 & -12.1 & -4.7 & -6.3 & -10.9 & -11.1 & -6.3 & -6.0 & -4.9 & -3.8 \\
\hline Public sector external assets $4 /$ & 316.1 & 260.1 & 250.7 & 265.6 & 265.5 & 307.5 & 347.9 & 382.5 & 414.2 & 440.2 \\
\hline & & & & cent of $\mathrm{C}$ & P, unles & otherwis & pecified & & & \\
\hline Saving-investment balance 5 / & & & & & & & & & & \\
\hline Final consumption & 57.2 & 47.9 & 43.2 & 42.7 & 38.2 & 40.4 & 42.4 & 44.0 & 45.7 & 47.3 \\
\hline Government & 19.1 & 14.9 & 13.7 & 13.8 & 12.8 & 13.5 & 13.9 & 14.2 & 14.5 & 14.8 \\
\hline Private & 38.2 & 33.0 & 29.5 & 28.9 & 25.4 & 26.8 & 28.5 & 29.8 & 31.2 & 32.5 \\
\hline Gross domestic investment & 18.2 & 16.4 & 15.2 & 20.3 & 21.3 & 23.7 & 25.4 & 27.1 & 28.4 & 29.6 \\
\hline Government & 3.7 & 3.0 & 2.9 & 6.0 & 6.8 & 8.2 & 8.9 & 9.4 & 9.9 & 10.3 \\
\hline Private & 14.5 & 13.5 & 12.4 & 14.3 & 14.5 & 15.5 & 16.5 & 17.7 & 18.6 & 19.3 \\
\hline Savings & 48.8 & 58.9 & 67.0 & 67.6 & 66.5 & 66.0 & 70.0 & 69.7 & 69.8 & 69.9 \\
\hline Government Saving & 37.8 & 47.3 & 56.4 & 59.3 & 55.9 & 55.6 & 56.2 & 55.2 & 53.5 & 51.7 \\
\hline Private Savings & 11.0 & 11.6 & 10.6 & 8.4 & 10.7 & 10.5 & 13.8 & 14.5 & 16.3 & 18.2 \\
\hline Real private consumption per capita (percentage change) & -2.3 & -1.1 & 0.9 & -1.6 & 2.3 & 2.0 & 2.0 & 2.0 & 2.0 & 2.0 \\
\hline Incremental Capital Output Ratio (reciprocal) & 0.43 & 0.57 & 0.50 & 0.46 & 0.36 & 0.33 & 0.32 & 0.30 & 0.30 & 0.30 \\
\hline
\end{tabular}

Sources: Kuwait authorities; IMF World Economic Outlook; and Fund staff estimates and projections.

1/ Fiscal year ending March 31.

2/ Includes profits of public enterprises.

3/ Non-oil primary deficit is defined as total revenues excluding oil revenues and KIA investment income minus non-interest expenditures.

4/ Staff estimates and projections, based mainly on balance of payment flow data and assuming return on foreign assets close to the LIBOR.

$5 /$ Domestic demand and net export do not add up to GDP because of the difference in available data coverage of balance of payments and national accounts. 
Table 6. Kuwait: Financial Soundness Indicators, 2003-07

\begin{tabular}{lrrrrr}
\hline & 2003 & 2004 & 2005 & 2006 & 2007 \\
& & & & & \\
& & & & & \\
\hline Core Set: & & & & & \\
Regulatory capital to risk-weighted assets & 18.4 & 17.3 & 21.3 & 21.8 & 20.4 \\
Nonperforming loans net of provisions to capital & 7.2 & 5.9 & $\ldots$ & 15.2 & 12.6 \\
Nonperforming loans to gross loans & 6.1 & 5.3 & 5.0 & 3.9 & 3.2 \\
$\quad$ Nonperforming loans from before invasion & 3.6 & 2.9 & 2.2 & 1.8 & 1.4 \\
$\quad$ Nonperforming loans since liberation & 2.5 & 2.4 & 2.8 & 2.1 & 1.8 \\
Return on assets & 2.0 & 2.5 & 3.0 & 3.2 & 3.4 \\
Return on equity & 18.6 & 20.9 & 22.9 & 27.1 & 28.1 \\
Liquid assets to total assets & 14.8 & 13.2 & 11.1 & 8.1 & 7.0 \\
Liquid assets to short-term liabilities & 52.3 & 52.0 & 47.8 & $\ldots$ & $\ldots$ \\
Net open position in foreign exchange to capital and reserves & 4.2 & 8.7 & 7.4 & 1.4 & 1.1 \\
Encouraged Set: & & & & & \\
Capital to assets & & & & & \\
Average lending rate 1/ & 10.7 & 12.1 & 12.7 & 11.7 & 12.0 \\
Average deposits rate 1/ & 5.4 & 5.6 & 7.5 & 8.8 & 8.3 \\
Spread over 3-month deposit rate 1/ & 2.4 & 2.7 & 3.5 & 5.5 & 5.3 \\
Foreign-currency-denominated assets to total assets & 3.0 & 3.0 & 4.0 & 3.3 & 3.0 \\
Foreign-currency-denominated liabilities to total assets & 18.4 & 21.2 & 18.3 & 21.4 & 22.8 \\
Loan provisions to nonperforming loans & 17.9 & 20.2 & 17.3 & 21.8 & 24.0 \\
Ratio of banks' lending to banks' capital & 77.7 & 82.5 & 107.2 & 95.8 & 92.0 \\
Stock market related 2/ & & & & & \\
Real estate 3/ & 37.6 & 39.3 & 44.6 & 50.6 & 48.2 \\
Total (stock market plus real estate) & 71.4 & 87.8 & 90.7 & 103.7 & 115.9 \\
Investment companies' capital and reserves to total assets $4 /$ & 109.0 & 127.1 & 135.3 & 154.3 & 164.1 \\
& 30.3 & 30.3 & 36.2 & 35.4 & 34.8 \\
\hline & & & & &
\end{tabular}

Source: Central Bank of Kuwait.

1/ For local banks.

2/ Includes lending for stock purchases of listed and unlisted domestic and foreign companies.

3 / Includes only credit to developers (excludes credit to home buyers). Ratios may be overestimated due to problems with loan classification by the local banks.

4/ Excluding Islamic institutions. 
Table 7. Kuwait: Vulnerability Indicators, 2002-07

\begin{tabular}{|c|c|c|c|c|c|c|}
\hline & 2002 & 2003 & 2004 & 2005 & $\begin{array}{l}\text { Prel. } \\
2006\end{array}$ & $\begin{array}{l}\text { Proj. } \\
2007\end{array}$ \\
\hline & \multicolumn{6}{|c|}{ (In percent, unless otherwise indicated) } \\
\hline \multicolumn{7}{|l|}{ External solvency indicators } \\
\hline REER (CPI based, period average) 1/ & -1.0 & -7.2 & -5.1 & 2.1 & 0.8 & 1.9 \\
\hline External debt including private sector (in billions of U.S. dollars) & 12.3 & 12.2 & 12.1 & 16.5 & 26.4 & 26.3 \\
\hline Short-term debt (original maturity; in billions of U.S. dollars) $2 /$ & 4.9 & 5.9 & 5.9 & 8.0 & 12.8 & 12.7 \\
\hline Medium- and long-term debt (in billions of U.S. dollars) $3 /$ & 7.4 & 6.4 & 6.3 & 8.5 & 13.6 & 13.6 \\
\hline External debt/GDP $4 /$ & 32.1 & 25.6 & 20.4 & 20.4 & 26.8 & 23.6 \\
\hline External debt/total exports of goods and services & 72.1 & 49.0 & 35.8 & 31.9 & 40.2 & 35.0 \\
\hline Short-term debt/total exports of goods and services & 28.8 & 23.5 & 17.4 & 15.5 & 19.5 & 16.9 \\
\hline External debt service/total exports of goods and services & -4.5 & -4.8 & -3.7 & -1.7 & -2.3 & $\ldots$ \\
\hline \multicolumn{7}{|l|}{ Public sector solvency indicators } \\
\hline General government domestic debt/GDP 5/ & 29.9 & 23.0 & 17.3 & 11.8 & 8.5 & 7.0 \\
\hline Interest payments/total revenue & 2.1 & 1.2 & 0.8 & 0.6 & 0.5 & 0.4 \\
\hline \multicolumn{7}{|l|}{ Distribution of the public domestic debt by holders } \\
\hline Local commercial banks & 93.6 & 93.0 & 90.7 & 88.4 & 89.0 & 87.7 \\
\hline Other (including nongovernment public institutions) & 6.4 & 7.0 & 9.3 & 11.1 & 11.0 & 12.3 \\
\hline Oil revenue/total revenue & 74.1 & 76.8 & 77.1 & 80.1 & 78.1 & 77.9 \\
\hline \multicolumn{7}{|l|}{ External liquidity indicators } \\
\hline CBK net foreign assets (in billions of U.S. dollars) & 8.4 & 6.7 & 7.3 & 8.1 & 11.8 & 15.9 \\
\hline CBK gross foreign assets (in billions of U.S. dollars) $6 /$ & 8.5 & 6.7 & 7.5 & 8.5 & 12.3 & 16.4 \\
\hline In months of imports of goods and services & 7.3 & 4.9 & 4.6 & 4.5 & 6.0 & 5.8 \\
\hline Relative to short-term external debt & 172.5 & 115.0 & 126.9 & 106.2 & 96.0 & 128.6 \\
\hline Relative to M0 & 429.1 & 288.1 & 279.3 & 268.1 & 294.6 & 243.1 \\
\hline Relative to M1 & 122.5 & 76.1 & 69.2 & 66.5 & 100.0 & 107.9 \\
\hline Local banks' net foreign assets (in billions of U.S. dollars) & 1.4 & 1.7 & 4.6 & 5.3 & 7.4 & 5.1 \\
\hline Foreign assets & 8.1 & 8.2 & 10.8 & 13.0 & 18.1 & 28.0 \\
\hline Foreign liabilities & 6.8 & 6.5 & 6.2 & 7.7 & 10.8 & 22.9 \\
\hline Oil exports/total exports & 91.5 & 89.8 & 92.3 & 93.9 & 94.9 & 95.0 \\
\hline
\end{tabular}

Sources: Central Bank of Kuwait; and Fund staff estimates.

$1 /$ Percentage changes in period's average.

2/ Short-term data are obtained from the joint BIS-IMF-OECD-World Bank database.

3 / Medium- and long-term debt is estimated as a residual.

4/ Include private sector's debt.

5/ Treasury bills and bonds, and debt purchase bonds.

6/ Excludes SDRs and IMF reserve position. 


\section{INTERNATIONAL MONETARY FUND}

\section{KUWAIT \\ 2008 Article IV Consultation \\ Informational Annex \\ Prepared by the Middle East and Central Asia Department}

April 2, 2008

Contents

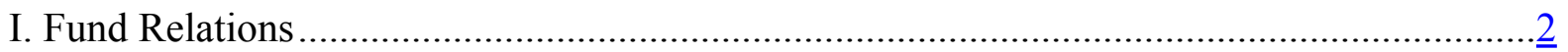

II. Relations with the World Bank Group ...........................................................................

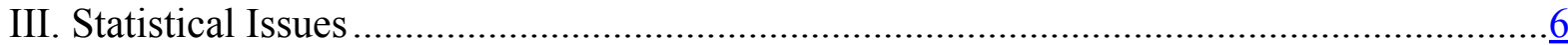




\section{APPENDIX I: KUWAIT-FUND RELATIONS}

(As of January 31, 2008)

I. Membership Status: Joined September 13, 1962

Article VIII on April 5, 1963

II. General Resources Account:

Quota

Fund holdings of currency

Reserve position in Fund

III. SDR Department:

Net cumulative allocation Holdings
SDR Million

$1,381.10$

$1,290.30$

90.82

SDR Million

26.74

146.15
\% Quota

100.00

93.43

6.58

$\%$ Allocation

100.00

546.46

IV. Outstanding Purchases and Loans: None

V. Financial Arrangements: None

VI. Lending to the Fund and Grants:

Kuwait has made a contribution to the PRGF-HIPC Trust in support of Fund's concessional assistance to low-income countries. These include an interest-free deposit of SDR 4.2 million with a maturity at end-2018, and a grant contribution of SDR 0.1 million to the PRGF-HIPC Trust.

\section{Exchange Rate Arrangement:}

Since May 2007, the Kuwaiti dinar has been pegged to an undisclosed currency basket, reverting to the exchange system before January 2003. Between January 1, 2003 and May 2007, the Kuwaiti dinar had been pegged to the U.S. dollar with a margin of 3.5 percent on either side around the parity exchange rate of 299.63 fils/U.S. dollar. On April 2, 2002 Kuwait notified the Fund, under Decision 144-(52/51), of exchange restrictions it introduced in order to implement UN Security Council resolutions 1373 (2001), 1333 (2000) and 1267 (1999).

\section{Article IV Consultations:}

The last Article IV consultation was completed by the Executive Board on April 6, 2007. The authorities decided not to publish the report.

\section{FSAP Participation}

An FSAP exercise was conducted in September 2003 in order to assess three international standards and codes (banking, securities, and AML/CFT). A FSSA report was discussed by 
the Executive Board along with the staff report for the 2003 Article IV consultation and was issued in May 2004, Country Report No. 04/151.

X. Technical Assistance:

STA Seminar on GDDS February 2000

STA National Accounts and Price Statistics

June 2001-June 2002

FAD Restructuring Budget Processes

January/February 2002

FAD A Program for Tax Reform

December 2002

MFD/LEG Bank Insolvency

October 2004

XI. Resident Representative: None

XII. Kuwait has consented to the quota increase under the Eleventh General Review of Quotas; it has accepted the Fourth Amendment of the Articles of Agreement. 


\section{APPENDIX II: KUWAIT-RELATIONS WITH THE WORLD BANK GROUP}

(As of March 13, 2008)

The Technical Cooperation agreement between the Government of Kuwait and the World Bank has been renewed for three years (January 1, 2007-December 31, 2009) for a nominal allocation of \$8 million.

\section{Ongoing Activities—FY 2008/09}

- Vision and Long-term Development Options Planning: The Government of Kuwait is attempting to reorganize its planning process based on determination of a vision for Kuwait, development of a long-term strategy based on the vision, and preparation of a five year development plan within the framework of the strategy. The Government requested the Bank's assistance with regard to the first two stages of the process. The vision and long-term strategy document will be prepared based on the extensive consultations and interviews that are currently underway in the country; the document is planned to be submitted to the Planning Committee for review in early February 2008.

- Civil Service Council: Review of the Civil Service Remuneration and Benefits System. In September 2007, the Government held discussions with the Bank to explore how the Civil Service Commission (CSC) can revise the structure of salary and benefits offered to government employees. The scope and the detailed TOR for the review have been agreed upon, and the task implementation is underway.

- Country Procurement Assessment (CPAR): The Government of Kuwait is exploring the possibility of joining WTO; as a part of this process, the Bank was asked to assist in the preparation of a Country Procurement Assessment Review (CPAR) and also in drafting new and modernized public procurement law and regulations. The Bank will analyze the current public procurement system including its policies, organization, procedures and practices and help develop/improve the ability to plan, manage and monitor the procurement process effectively. The task is scheduled to be competed in FY08.

- Governance and Anti-corruption Project: An agreement for this project is currently under discussion with the Deputy Prime Minister. The scope of the project will involve assistance in development of anti-corruption regulations, establishment of an agency in charge of enforcement of these policies, and cooperation with the civil society.

- Kuwait Petroleum Company (KPC): Support to KPC's privatization program continues in FY2007 and involves technical assistance on corporate governance, labor policies, internal communication, capacity building, and assessment of the completed privatization results as well as new opportunities for privatizing non-essential services.

- Offset Program: The offset program was established to encourage domestic private investment, by providing venture capital and project management. Based on the recommendations of the review of the offset program conducted by the Bank staff in 
2005, the Government established a National Offset Company (NOC). Currently the Bank is assisting NOC in developing its business plan.

- Economic Zones Development. The World Bank is assisting the Foreign Direct Investment Bureau and the Public Authorities for Industry in conducting assessment of the development opportunities for several economic and industrial zones in Kuwait. The Bank has procured consulting services for this purpose and is supervising consultants' work. The project is planned for completion at the end of FY2007.

- Public Authority for Industries (PAI). In addition to the feasibility study on an industrial zone development (see above), the PAI requested the Bank's technical assistance on the industrial city planning; the Bank and PAI are developing the process of utilizing the creative energy of the private sector with regard to city planning and creating and economically successful and environmentally sound habitat that would allow to decrease a population pressure on the capital city.

- Redesigning Business Registration Processes: Following up on a previous study on administrative barriers to investment, the World Bank was asked to streamline business registration processes. An action plan has been developed, and now the scope of implementation is under review.

- Education Indicators and Assessment Project: Following the completion of the "Education Expenditure Analysis" study, the Bank continues to provide assistance in implementing the recommendations. This is a six-year program, and outcomes of the 2007-08 work plan include the publication of the annual Kuwait Education Indicators report, capacity building in policy relevant data analysis, implementation of the TIMSS and PIRLS, and possible preparation of an education sector review. 


\section{APPENDIX III: KUWAIT-STATISTICAL ISSUES}

(As of March 13, 2008)

Macroeconomic data are adequate for surveillance, but there is scope for improved compilation of the national accounts and balance of payments statistics through better coordination among statistical agencies.

\section{National Accounts and Production}

Recent improvements of national accounts include: change of the base year for the constant price data to 2000 and the estimates of value added for subsidized goods and services of the public utilities sector through the use of input costs (the household expenditure survey was used previously). Starting from the final 2002 data, further improvements are planned for national accounts reflecting the adoption of the 1993 SNA, a sampling frame based on the establishment survey (2002), and the expansion of the coverage of questionnaires. Continued progress, especially in the estimation of value added for the oil sector, requires the dedication of adequate resources and improved coordination between the Ministries of Planning, Oil, and Finance. STA has provided technical assistance to the Ministry of Planning to improve national accounts and price data. It would be useful if the Central Bank of Kuwait (CBK) would publish oil sector information in the Quarterly Statistical Bulletin pertaining to output, refining, domestic consumption, export price for crude and refined products and the domestic price of petroleum products. These data are available from the Ministry of Oil.

\section{Price Statistics}

CPI weights are based on the 1999-2000 household expenditure survey and were introduced into the index for a reference year of 2002. An improved monthly CPI based on a revised basket has been published in monthly CPI bulletins with about one-month lag. The wholesale price index (WPI) needs to be developed into a producer price index (PPI) which is consistent with the national accounts and includes all domestically produced goods, exfactory, for the export and the domestic market. Timely and comprehensive labor force data are not available.

\section{Government Finance Statistics}

Annual GFS data are reported for publication in the Government Finance Statistics Yearbook (GFSY). The major components of its extrabudgetary revenues (investment income and transfers of profits of public institutions), extrabudgetary expenditures (interest on foreign debt and treasury paper), and financing operations conducted by two reserve funds are not reported. Data on investment income, and on interest on foreign debt and treasury paper, however, are usually provided to Article IV consultation missions. The authorities have made some progress in fiscal data presentation, but the lack of a suitable classification of data on the execution of the budget remains a constraint on monitoring effectively fiscal developments during the year. Moreover, data on the operations of the Public Institute for Social Security are not made available. Sharing of information between various government agencies could be improved. STA has indicated to the authorities that operations of the two reserve funds should be classified as part of government, as they perform activities for public 
policy purposes (management of debt and assets, and financing of the budget). To this end, reporting subannual GFS in the form of the Statement of Sources and Uses of Cash for the consolidated central government could be encouraged. The authorities have also been briefed on the IMF's ongoing work to enhance the transparency of fiscal accounts and presentations detailed in the "Code of Good Practices on Fiscal Transparency" and were encouraged to adopt some of the practices recommended in the Code. The Public Expenditure Management (PEM) system could usefully be strengthened.

\section{Monetary and Financial Statistics}

The CBK reports monetary data to STA on a regular and timely basis. Monetary and financial statistics based on the Standardized Report Forms (SRFs) have been finalized and will be published in the April 2008 issue of the International Financial Statistics Supplement. CBK needs to work further to distinguish a number of investment companies that accept deposits from other investment companies that do not accept deposits. Investment companies that accept deposits should appropriately be classified as part of the depository corporations sector. In the current SRFs, all investment companies (including those that accept deposits) are classified as other financial corporations. However, the amount of deposits accepted by investment companies are considered as not significant. CBK staff attended a workshop on harmonizing monetary and financial statistics in the GCC region that was conducted by STA staff in Riyadh in July 2006

\section{Balance of Payments Statistics}

The CBK compiles and disseminates detailed annual data in accordance with the methodology of the BPM5-quarterly data are provided to Article IV consultation missions. However, data on capital flows of the nonfinancial private sector are limited, which has likely contributed to the "errors and omissions" item. To improve coverage for inward foreign direct investment, the CBK is making efforts to obtain more data by surveying direct investment enterprises identified by the Ministry of Finance. Enhancements have been made in the estimation of travel services and communication services, but further improvements are needed in compilation practices and in the estimation of data on several service items and private transfers.

A major step forward in 2007 was the dissemination of IIP data for 2001-2006 in STA publications. However, IIP data exclude the external assets held by the general government due to legal constraints on dissemination (however, loans granted by the Kuwaiti Fund for Arab Economic Development and general government trade credits are included).

The CBK also participated in 2007 in the Coordinated Portfolio Investment Survey (CPIS) with data reported for 2003-2006. These data are for the financial sector acting as end-investors or as intermediaries on behalf of residents and do not include holdings of foreign securities held by government agencies, which comprise the bulk of Kuwait's cross-border holdings. 


\section{Data dissemination}

Kuwait is one of the first GDDS participants. However, most of its metadata, with the exception of the real sector and socio-demographic metadata, have not been updated since October 2002. The CBK maintains its own webpage where it provides the following data to the public: money and banking statistics; balance of payments statistics; trade balance statistics; exchange rate; GDP by sector and expenditure at current and constant prices; public finance statistics; CPI and WPI; and security market indicators. Similarly, the Ministry of Planning has a webpage where the CSO publishes data on national accounts, prices, and other related statistics. The Ministry of Finance webpage includes detailed data for actual and estimated budget operations. In addition, the Kuwait Stock Exchange webpage provides data on stock market indices, volume and value of securities traded, as well as privatization schedules and other related information. 
KUWAIT: TABLE OF COMMON INDICATORS REQUIRED FOR SURVEILLANCE (AS OF MARCH 11, 2008)

\begin{tabular}{|c|c|c|c|c|c|}
\hline & $\begin{array}{c}\text { Date of } \\
\text { latest } \\
\text { observation }\end{array}$ & $\begin{array}{l}\text { Date } \\
\text { received }\end{array}$ & $\begin{array}{c}\text { Frequency } \\
\text { of } \\
\text { Data }^{1}\end{array}$ & $\begin{array}{l}\text { Frequency } \\
\text { of } \\
\text { Reporting }^{1}\end{array}$ & $\begin{array}{l}\text { Frequency } \\
\text { of } \\
\text { publication }\end{array}$ \\
\hline Exchange Rates & $2 / 2008$ & $3 / 2008$ & M & M & M \\
\hline $\begin{array}{l}\text { International Reserve Assets and Reserve Liabilities } \\
\text { of the Monetary Authorities }\end{array}$ & $11 / 2007$ & $11 / 2007$ & M & M & M \\
\hline Reserve/Base Money & $1 / 2008$ & $3 / 2008$ & M & M & M, Q \\
\hline Broad Money & $1 / 2008$ & $3 / 2008$ & M & M & $\mathrm{M}, \mathrm{Q}$ \\
\hline Central Bank Balance Sheet & $1 / 2008$ & $3 / 2008$ & M & M & $\mathrm{M}, \mathrm{Q}$ \\
\hline Consolidated Balance Sheet of the Banking System & $1 / 2008$ & $3 / 2008$ & M & M & M \\
\hline Interest Rates & $1 / 2008$ & $2 / 2008$ & M & M & M \\
\hline Consumer Price Index & $10 / 2007$ & $2 / 2008$ & M & Q & Q \\
\hline \multicolumn{6}{|l|}{$\begin{array}{l}\text { Revenue, Expenditure, Balance and Composition of } \\
\text { Financing - General Government }\end{array}$} \\
\hline $\begin{array}{l}\text { Revenue, Expenditure, Balance and Composition of } \\
\text { Financing- Central Government }{ }^{3}\end{array}$ & $3 / 2007$ & $5 / 2007$ & $A^{4}$ & A & $\begin{array}{r}\text { Not } \\
\text { published } \\
\text { on Fund } \\
\text { standards }\end{array}$ \\
\hline $\begin{array}{l}\text { Stocks of Central Government and Central } \\
\text { Government-Guaranteed Debt }\end{array}$ & $9 / 2006$ & $10 / 2006$ & M & M & M \\
\hline External Current Account Balance & 2006 & $7 / 2007$ & A & A & A \\
\hline Exports and Imports of Goods and Services & $12 / 2006$ & $7 / 2007$ & M & Q & Q \\
\hline GDP/GNP & 2006 & $6 / 2007$ & A & A & A \\
\hline Gross External Debt $^{5}$ & 2005 & $12 / 2006$ & A & A & A \\
\hline
\end{tabular}

1/ Daily (D), Weekly (W), Monthly (M), Quarterly (Q), Annually (A); NA: Not Available

2/ Central Bank of Kuwait only.

3 / Fiscal year data only.

4/ Higher frequency data available only in national format.

5/ Primarily private sector; except for a small volume of trade credits, Kuwait has no public external debt. 


\section{Statement by the IMF Staff Representatives April 18, 2008}

1. This statement summarizes information that has become available since the staff report on Kuwait was circulated to the Executive Board on April 3, 2008. The new information does not change the thrust of the staff appraisal.

2. Kuwait's Government resigned on March 17, partly reflecting difficulties in reaching consensus with parliament on public expenditures. Subsequently, Emir Sheikh Sabah Al-Ahmad dissolved the parliament and set new elections for May 17, 2008. The previous government remains in office as caretaker.

3. The state budget for $2008 / 09$ that had been approved by the Council of Ministers and submitted to parliament in January 2008 has already taken effect. It will be formally issued by Amiri decree to become law. The parliament elected in May will have the right to review all decrees issued in the absence of parliament and may approve them with or without amendment.

4. Inflationary pressures continued. Inflation declined somewhat to 6.7 percent $(y / y)$ in November, but subsequently rose to 7.5 percent (y/y) in December 2007. In addition to the global increase in commodity and food prices, inflation was fuelled by a 12.6 percent increase in rents. As of end-March 2008, the Kuwaiti Dinar/U.S. dollar exchange rate had appreciated by 8.2 percent since the move to a basket peg in May 2007. In January 2008, the Central Bank of Kuwait (CBK) cut the REPO rate by 50 basis points to 3.5 percent and the discount rate from 6.25 to 5.75 percent.

5. On March 24, 2008, the Central Bank of Kuwait (CBK) took several measures, with a view to contain consumer credit growth, in part by making bank lending less attractive. These measures include: (a) reducing the maximum monthly installment than can be charged under consumer and installment loans from 50 to 40 percent of clients' net salary or monthly income, and to 30 percent for pensioners; (b) reducing the maximum interest rate on such loans from 4 to 3 percent above the discount rate; (c) fixing the interest rate on this type of loans for five years instead of allowing it to change with changes in the discount rate; and (d) prohibiting banks from charging interest on this type of loans upfront. The CBK has also intensified efforts through moral suasion to ensure bank lending remains prudent.

6. Kuwait's stock market index gained 14 percent during the first quarter of 2008, following its 24 percent gain in 2007.

7. Recent data indicate that imports in 2007 were higher by $\$ 3$ billion than estimated in the staff report; exports were broadly in line with estimates.

8. The Kuwait planning council has recently released an ambitious five-year plan (2009-14) that envisages significant reforms to boost the non-oil economy and attract more 
foreign investment to improve Kuwait's competitiveness as a financial hub in the region. The plan proposes speeding up of privatization, including reducing the government share in land ownership from the present 90 percent. At the same time, the plan calls for large investments in infrastructure. Rationalization of the welfare system is also envisaged. 
Public Information Notice (PIN) No. 08/67 FOR IMMEDIATE RELEASE June 12, 2008
International Monetary Fund $70019^{\text {th }}$ Street, NW

Washington, D. C. 20431 USA

\section{IMF Executive Board Concludes 2008 Article IV Consultation with Kuwait}

On April 18, 2008, the Executive Board of the International Monetary Fund (IMF) concluded the Article IV consultation with Kuwait. ${ }^{1}$

\section{Background}

Kuwait's macroeconomic performance has been strong in 2007 with prudent macroeconomic management supporting high growth especially in the non-oil economy. The large increase in oil revenue generated substantial fiscal and external current account surpluses, enabling the country to build up its foreign assets. Structural reforms continued, aimed at promoting a dynamic private sector driven economy and enhance incentives for bringing in foreign know-how. Inflation has been gradually picking up, reaching 7.3 percent year-on-year in October 2007, driven both by domestic demand pressures (especially rents) and higher import prices (mostly food).

Real GDP growth in 2007 is estimated at 4.6 percent. Kuwait's oil production has declined by 2.6 percent in 2007 , in line with the OPEC decisions, while non-oil activityparticularly in financial, transportation, and communication services-grew by almost 9 percent per annum, benefiting from a surge in investment and expansionary macroeconomic policies.

\footnotetext{
${ }^{1}$ Under Article IV of the IMF's Articles of Agreement, the IMF holds bilateral discussions with members, usually every year. A staff team visits the country, collects economic and financial information, and discusses with officials the country's economic developments and policies. On return to headquarters, the staff prepares a report, which forms the basis for discussion by the Executive Board. At the conclusion of the discussion, the Managing Director, as Chairman of the Board, summarizes the views of Executive Directors, and this summary is transmitted to the country's authorities. This PIN summarizes the views of the Executive Board as expressed during the April 2008 Executive Board discussion based on the staff report.
} 
The fiscal surplus is estimated to have increased to 40 percent of GDP in FY2007/08 (ended March 31), but is projected to narrow in FY2008/09 due to a large transfer to the Kuwait Public Institution for Social Security (KPISS) to strengthen the financial position of the public pension system, and large increases in public wages, transfers and subsidies, and capital expenditure.

Kuwait abandoned the peg to the U.S. dollar in May 2007, and has since pegged the Kuwaiti dinar (KD) to an undisclosed basket of currencies in order to dampen imported inflation related to rising world food prices and the depreciation of the U.S. dollar. The real effective exchange rate (REER) of the Kuwaiti dinar appreciated by about 2 percent in 2007, largely due to a 6 percent appreciation against the U.S. dollar and relatively higher inflation.

Broad money and credit to the private sector expanded rapidly in 2007. Within the constraints of the peg, the central bank of Kuwait sought to contain the expansion of monetary aggregates by tightening the loan-to-deposit ceiling, and to dampen capital inflows by driving down the KD interbank rate (KIBOR) below LIBOR. After a moderate correction in 2006 (12 percent), the Kuwait stock exchange (KSE) recovered strongly in 2007 with the KSE index gaining 25 percent; it fell again in early 2008 as global turbulences intensified.

Structural reforms to promote a dynamic private sector driven open economy gained momentum. The profit tax on foreign investors has been reduced from 55 percent to 15 percent and capital gains from stock investment have become exempt from tax, removing an important obstacle for the flow of foreign investment into the country. The national assembly also approved the Sale of State Properties Law. The law sets guidelines for the government to provide state land to local or foreign investors, and provides a legal basis for projects based on public-private partnerships. Parliament also approved a bill authorizing the privatization of Kuwait Airways, the first major privatization in Kuwait. The government granted licenses to three private airlines and four new private universities, and privatized a number of gas stations. Budget preparation (including the wage bill and the capital budget) has been consolidated in the ministry of finance, strengthening further the fiscal framework.

Kuwait's macroeconomic vulnerabilities remain low. As a large international creditor, Kuwait is not vulnerable to capital flow reversals, and could maintain macro-stability even if faced with a sizable drop in oil prices. To date Kuwait's financial system has weathered the recent turbulences in global financial markets rather well. Kuwait banking system is sound and available financial soundness indicators through September 2007 point to strong capitalization, asset quality, and profitability.

\section{Executive Board Assessment}

Executive Directors commended the Kuwaiti authorities' prudent macroeconomic policies and structural reform efforts which, in combination with higher oil prices, have contributed to strong growth, especially in the labor-intensive non-oil sector. Directors 
agreed that dealing with inflation pressures will be a priority for the near term. Vigorous implementation of the government's reform plans should help support the favorable medium-term growth prospects for both the oil and non-oil sectors.

Directors commended the Kuwaiti authorities' intention to continue to play a constructive role in the global oil market. They welcomed plans to increase oil production and refinery capacity, which would help support global oil market stability.

Directors highlighted Kuwait's strong fiscal position, which enhances the economy's resilience against shocks. Going forward, they agreed that fiscal policies must strike a delicate balance between moderating demand pressures, addressing domestic supply bottlenecks, and building up financial assets for future generations and to reduce dependence on volatile oil revenue. The wage bill and subsidies should be contained through merit-based wage increases and better-targeted social spending. Directors welcomed plans to close the actuarial deficit of the Pension Fund and recommended to build on recent improvements in budget planning and execution by adopting a mediumterm budget preparation framework.

Directors welcomed the stabilizing role being played by the Kuwait Investment Authority (KIA), both domestically and in global financial markets. Some Directors saw scope for greater transparency regarding the KIA's financial position. They also encouraged the authorities to participate in the initiative to formulate a set of best practices for sovereign wealth funds. A few other Directors, however, shared the authorities' reservations regarding participation in the development of such best practices.

Most Directors agreed that the pegged exchange rate regime remains appropriate for Kuwait, and that the recent move to a basket peg may have been helpful in containing imported inflation. However, the peg limits the active use of interest rate policy, and some Directors suggested that there may be a case for reviewing the nature of the exchange rate arrangement. Directors considered that, to counter rising domestic inflationary pressures, the supply response in the nontradables sector-in particular in housing and land-will need to be enhanced, in the context of maintaining fiscal policy prudence. Containing domestic credit growth through continued supervisory vigilance will also be needed.

Regarding the real exchange rate of the Kuwaiti dinar, most Directors concurred that, while the surge in oil prices in recent years may have contributed to some undervaluation, the recent moderate currency appreciation and rising inflation are moving the real exchange rate closer to its equilibrium level. At the same time, Directors recognized the methodological difficulties surrounding the assessment of exchange rate equilibrium for oil exporting countries, and looked forward to further work on these issues.

Directors welcomed Kuwait's commitment to Gulf Cooperation Council (GCC) monetary union, but noted that its implementation by 2010 will require speeding up the building of an appropriate institutional framework. In line with the GCC common market agreement, they encouraged the authorities to work toward removing remaining obstacles to the flow of labor and capital among GCC countries. Several Directors looked forward to the 
forthcoming staff paper on the options for the exchange rate arrangement under the planned monetary union.

Directors noted the sound position of the banking sector, while cautioning that the rapid growth of financial investment companies calls for continued vigilance. They encouraged the authorities to complete the implementation of outstanding Financial Sector Assessment Program (FSAP) recommendations, including establishing a unified and independent capital market regulatory authority applying best international practices, and to continue and broaden regular stress testing of the overall financial sector.

Directors stressed that further structural reforms will be critical to sustain growth over the medium term, and welcomed in this context the authorities' ongoing efforts to promote private sector growth and improve the investment climate. Focusing public expenditure primarily on infrastructure and education, rather than on subsidies and transfers, would help develop human capital and create private sector employment opportunities for Kuwaiti nationals. The establishment of a strong capital market regulator, along with legal reforms to encourage competition and facilitate doing business, will help promote the private sector as the main engine of growth and employment.

Directors welcomed the authorities' intention to improve economic statistics, and encouraged them to adopt a program aimed at subscribing to the Fund's Special Data Dissemination Standard (SDDS).

Directors commended the authorities for their substantial development assistance and their active support for the Highly Indebted Poor Countries (HIPC) Initiative. They encouraged the authorities to extend HIPC debt relief to claims held by the Kuwait Investment Authority.

Public Information Notices (PINs) are issued, (i) at the request of a member country, following the conclusion of the Article IV consultation for countries seeking to make known the views of the IMF to the public. This action is intended to strengthen IMF surveillance over the economic policies of member countries by increasing the transparency of the IMF's assessment of these policies; and (ii) following policy discussions in the Executive Board at the decision of the Board. 


\section{Kuwait: Selected Economic Indicators, 2003-08}

\begin{tabular}{|c|c|c|c|c|c|c|}
\hline & 2003 & 2004 & $\begin{array}{c}2005 \\
\text { (Percen }\end{array}$ & $\begin{array}{c}2006 \\
\text { change) }\end{array}$ & $\frac{\text { Est. }}{2007}$ & $\frac{\text { Proj. }}{2008}$ \\
\hline \multicolumn{7}{|l|}{ Production and prices } \\
\hline Real GDP & 17.2 & 10.6 & 11.5 & 6.4 & 4.6 & 6.0 \\
\hline Real oil GDP & 19.8 & 8.1 & 11.4 & 2.9 & -2.3 & 1.3 \\
\hline Real non-oil GDP & 13.9 & 12.9 & 12.0 & 9.4 & 9.2 & 8.6 \\
\hline Consumer Price Index (annual average) & 1.0 & 1.3 & 4.1 & 3.1 & 5.0 & 6.5 \\
\hline & \multicolumn{6}{|c|}{ (In percent of GDP) } \\
\hline \multicolumn{7}{|l|}{ Government finances $1 /$} \\
\hline Total Revenue, of which: & 52.9 & 55.7 & 64.5 & 64.0 & 72.6 & 70.3 \\
\hline Oil and gas & 40.8 & 42.9 & 52.1 & 49.5 & 56.6 & 58.0 \\
\hline Investment income & 7.7 & 9.3 & 9.8 & 11.5 & 13.6 & 10.2 \\
\hline Total Expenditure & 36.2 & 32.8 & 27.4 & 35.0 & 32.2 & 45.8 \\
\hline Current & 31.7 & 28.6 & 23.8 & 30.9 & 24.7 & 37.8 \\
\hline Capital & 4.5 & 4.2 & 3.6 & 4.2 & 7.4 & 7.9 \\
\hline Overall fiscal balance & 16.7 & 22.9 & 37.1 & 29.0 & 40.5 & 24.5 \\
\hline & \multicolumn{6}{|c|}{ (Percent change) } \\
\hline \multicolumn{7}{|l|}{ Money and credit } \\
\hline Broad money & 7.8 & 12.1 & 12.3 & 21.7 & 19.3 & 14.3 \\
\hline Interest Rate $2 /$ & 1.5 & 1.6 & 2.9 & 5.0 & 5.2 & \\
\hline Claims on nongovernment sector & 21.4 & 16.1 & 18.8 & 24.8 & 35.1 & 18.6 \\
\hline & \multicolumn{6}{|c|}{ (In billions of U.S. dollars; unless otherwise indicated) } \\
\hline \multicolumn{7}{|c|}{ 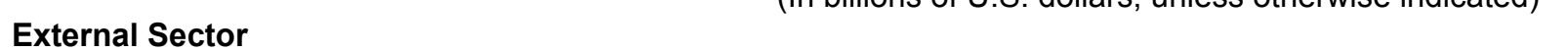 } \\
\hline Exports, of which: & 21.8 & 30.1 & 47.0 & 58.6 & 62.8 & 84.7 \\
\hline Crude oil and refined products & 19.6 & 27.8 & 44.1 & 55.7 & 59.7 & 81.4 \\
\hline Imports & -9.9 & -11.7 & -14.2 & -14.3 & -16.7 & -19.9 \\
\hline Current account balance (deficit $=-$ ) & 9.4 & 18.2 & 34.3 & 51.1 & 52.7 & 65.6 \\
\hline In percent of GDP & 19.7 & 30.6 & 42.5 & 51.7 & 47.4 & 45.2 \\
\hline International reserve assets & 7.6 & 8.3 & 9.0 & 12.6 & 15.5 & 18.6 \\
\hline In months of imports of goods and services & 5.5 & 5.2 & 4.7 & 6.1 & 5.5 & 5.7 \\
\hline Real effective exchange rate (percent change) & -7.2 & -5.1 & 2.1 & 0.8 & 1.9 & $\ldots$ \\
\hline
\end{tabular}

Sources: Data provided by the authorities; and Fund staff estimates.

1/ Fiscal year ending March 31.

2/ Three-month Kuwaiti dinar deposit rate (period average). 


\section{Statement by A. Shakour Shaalan, Executive Director for Kuwait April 18, 2008}

1. On behalf of the Kuwaiti authorities, I thank staff for their continued engagement with Kuwait and a helpful and constructive Article IV consultation report. The Kuwaiti authorities attach particular importance to the views of the Executive Board, Management, and the staff regarding the economic policies and prospects of Kuwait.

\section{Recent Developments}

2. Underpinned by sustained prudent macroeconomic policies and structural reforms, a pick-up in investment, as well as higher oil prices, Kuwait's macroeconomic performance strengthened further in 2007. This is reflected in buoyant growth in the non-oil economy, increasing private sector employment for Kuwaiti and non-Kuwaiti nationals, and substantial fiscal and external current account surpluses. Price pressures has however picked up somewhat, driven by domestic demand pressures and higher import prices, notably food. This appears to be a general worldwide phenomenon.

3. These developments were accompanied by a continuation of fiscal reforms and measures aimed at enhancing the environment for private sector activity. A schedule to close the actuarial deficit of the Kuwait Public Institute for Social Security (KPISS) by 2009 was announced. The fiscal framework was further strengthened by consolidating the budget preparation process in the Ministry of Finance. Moreover, measures to facilitate the flow of foreign investment into the country, including reducing taxes on foreign investors, were introduced. The national assembly approved the Sale of State Properties Law, enabling the government to provide state land to local or foreign investors, and providing a legal basis for projects based on public-private partnerships. It also expanded the privatization program. These efforts to further diversify the economy, together with increased spending on infrastructure, education and public services, as well as plans to expand oil production and refining capacity, bode well for sustainable high growth over the medium term.

4. Kuwait is fully aware of its responsibilities as a major oil producer, and remains committed to supporting global oil market stability. To this end, it has launched an ambitious $\$ 50$ billion investment program to expand both its upstream and downstream production capacity. The plan aims at raising production capacity to 4 million barrels per day (mbpd) by 2020 and doubling refining capacity to about $1.4 \mathrm{mbpd}$ by $2012-13$. It would be essentially financed by the Kuwait Petroleum Corporation's own resources, with strong private participation in the downstream sector.

\section{Fiscal Policy and Reforms}

5. Higher oil revenues have contributed to a significant improvement in the fiscal position last year, with the overall fiscal surplus estimated at about 40 percent of GDP in FY2007/08, despite a substantial increase in capital spending. In spite of increasing pressure on the budget engendered by the favorable fiscal position, the authorities remain committed to fiscal prudence. In addition to containing recurrent spending by limiting increases in 
public sector salaries and benefits, the authorities are cognizant that further increases in subsidies will add to price distortions and the misallocation of resources.

6. The focus on enhancing the structure of public finances will be maintained. To this end, the authorities plan sizable transfers from the budget to close the remaining KPISS actuarial deficit over the next two years and are considering reforming the contribution and benefits rules to ensure the viability of the system. In addition to progress achieved in the consolidation of the budgetary process, future reforms include better anchoring of one-year budgets in rolling medium-term fiscal frameworks and introducing GFSM 2001 accounting. Efforts are also ongoing to coordinate with other GCC members the introduction of a valueadded tax and the harmonization of tax laws.

7. The authorities however remain unconvinced that greater transparency in the financial operations of the Kuwait Investment Authority (KIA) and KPISS would support their fiscal strategy or help avert protectionist measures in countries where the growing role of sovereign wealth funds (SWFs) has raised concerns. They wish to emphasize that KIA currently manages two highly efficient saving funds. Adequate safeguard arrangements are in place with regard to the management of these resources, which are overseen by the KIA Board of Directors, internal and external auditors and the Public Audit Office. Moreover, rigorous biannual parliament oversight ensures proper accountability. Furthermore, although legal constraints prohibit the publication of KIA's balance sheet and income statements, the data is widely reported in the media as noted by staff.

8. The authorities share staff's assessment in the April 2008 Global Financial Stability Report regarding the stabilizing role of SWFs in global financial markets, particularly in strengthening bank balance sheets through sizable injections of capital. They wish to emphasize that KIA's investment policy is purely commercially driven and respects regulations in the financial markets it invests in. While the authorities hope that the Fund would play a constructive role in ensuring a positive dialogue between SWFs and recipient countries, they remain to be convinced of the need for a code of "best practices." In the authorities' view, this would risk disrupting the flow of sizeable long-term capital from SWFs to institutions in the U.S. and elsewhere that face both liquidity and capital needs.

\section{Monetary and Exchange Rate Policies}

9. In the context of the pegged exchange regime, and against the background of demand and import-driven inflationary pressures, the Central Bank of Kuwait (CBK) aimed at dampening capital inflows by reducing the Kuwaiti dinar interbank rate below LIBOR, while relying on prudential measures to contain the expansion of private credit. In the period ahead, the authorities recognize the importance of pursuing efforts to enhance the supply response in the nontradable sector, further strengthening the fiscal policy framework, and containing credit growth, to reduce inflationary pressures.

10. The authorities share staff's assessment regarding the adequacy of the pegged exchange rate regime, given Kuwait's openness, structure of financial markets, and the plans for regional monetary union. The recent move to a basket peg should, in their view, create some room for maneuver in relation to U.S. monetary policy, in view of the differences in the 
two countries' cyclical positions, while better aligning the peg with Kuwait's trading and investment patterns. The authorities reiterate their intention to join the planned GCC monetary union by 2010 .

\section{External Developments and Policies}

11. The authorities consider that the current and planned policy mix will lead to domestic and external stability over the medium term. Indeed, while substantial external account surpluses have been recorded over the past years due to higher oil prices, surpluses are expected to decline over the medium term as domestic demand and imports rise further. It should also be stressed that surpluses in oil-exporting countries are different in nature from those of other countries as they are a result of exports of non-renewable resources to meet global demand. It is therefore critical to use these surpluses effectively to (i) raise the growth potential of the economy through high levels of public investments in infrastructure and social areas; and (ii) accumulate savings through large fiscal and current account surpluses to help ensure intergenerational equity, reduce dependence on oil revenues, and smooth out fluctuations in revenue in the coming years. All these factors should be reflected in equilibrium exchange rate calculations, which currently present serious methodological weaknesses. These are further compounded in the case of oil-exporting countries by the high degree of volatility in oil prices. Moreover, the standard notion of currency undervaluation should not apply since Kuwait is not gaining market share at the expense of other countries. Finally, current account balances are determined mostly by fiscal policy with little role for the exchange rate. Accordingly, reducing Kuwait's current account surplus would involve either greater fiscal expansion at the risk of creating higher inflation, or reduced oil production, which is not a desirable solution for both oil producers and consumers.

\section{Financial Sector Issues}

12. Benefiting from the rapid expansion in the economy, Kuwait's banking sector continues to enjoy comfortable levels of profits and capitalization. It remains well supervised and appears to be weathering the current financial turmoil well. Good progress has been made in implementing the 2003 FSAP recommendations, as all measures pertaining to the central bank have been implemented, except for the removal of the ceiling on lending rates which would require parliamentary approval. Further refinement in the periodic stress-testing of banks attests to the commitment to strengthen the banking sector's resilience to the rapid increase in credit and the direct and indirect exposure to domestic and international stock and real estate markets. The authorities appreciate the focus in Box 2 on investment companies whose number, size, and activities have significantly grown over the last few years, making that sector systemically important. While the CBK is comfortable with the overall current regulatory framework, which covers disclosure, credit concentration and provisioning, antimoney laundering, and consumer/installment loans limits, it will continue to carefully watch individual banks' exposures to investment companies.

\section{Statistical and Other Issues}

13. Notwithstanding progress achieved in improving the quality and dissemination of economic data, the Kuwaiti authorities remain strongly committed to further improvements. 
They fully recognize the need to improve the production of the CPI, especially given the importance of current inflationary developments for economic policy.

14. Kuwait continues to provide substantial assistance to developing countries. Its development assistance, estimated at about 2 percent of GDP on average over the past 20 years, significantly exceeds the U.N. target. Kuwait is a strong supporter of the HIPC Initiative and is currently considering ways to extend HIPC debt relief to claims held by KIA. 